\title{
Life cycle assessment of hydrogenated biodiesel production from waste cooking oil using the catalytic cracking and hydrogenation method.
}

\section{$\operatorname{AUTHOR(S):~}$}

Yano, Junya; Aoki, Tatsuki; Nakamura, Kazuo; Yamada, Kazuo; Sakai, Shin-ichi

\section{CITATION:}

Yano, Junya ...[et al]. Life cycle assessment of hydrogenated biodiesel production from waste cooking oil using the catalytic cracking and hydrogenation method.. Waste management 2015, 38: 409-423

\section{ISSUE DATE:}

2015-04

URL:

http://hdl.handle.net/2433/201849

\section{RIGHT:}

(C) 2015. This manuscript version is made available under the CC-BY-NC-ND 4.0 license http://creativecommons.org/licenses/by-nc-nd/4.0/; The full-text file will be made open to the public on 01 May 2017 in accordance with publisher's 'Terms and Conditions for Self-Archiving'. 
Life Cycle Assessment of Hydrogenated Biodiesel Production from Waste Cooking Oil Using the Catalytic Cracking and Hydrogenation Method

\section{Author names and affiliations}

Junya YANO*, Tatsuki AOKI*, Kazuo NAKAMURA**, Kazuo YAMADA***, Shin-ichi SAKAI *

*Environment Preservation Research Center, Kyoto University, Yoshida-Honmachi, Sakyo-ku, Kyoto 606-8501, Japan

**Advanced Scientific Technology \& Management, 134 Chudoji Minamimachi, Shimogyo-ku, Kyoto 606-8813, Japan

*** Kyoto City Environmental Policy Bureau, 384 Ichinofunairicho, Nakagyo-ku, Kyoto 604-0924, Japan

\section{Corresponding author}

Junya YANO

Environment Preservation Research Center, Kyoto University, Yoshida-Honmachi, Sakyo-ku, Kyoto 606-8501, Japan

E-mail: yano@eprc.kyoto-u.ac.jp

Phone: +81-75-753-7709 


\section{Highlights}

- LCA with uncertainty analysis was conducted for BDF production from waste cooking oil.

- HBD production scenario reduced total environmental impacts by $50-71 \%$ compared with incineration.

- FAME-type BDF provides limited future benefit compared with fossil-derived diesel.

- A shift from FAME-type BDF to HBD would more effectively reduce total environmental impacts. 


\section{Abstract}

2 There is a worldwide trend towards stricter control of diesel exhaust emissions, however 3 presently, there are technical impediments to the use of FAME (fatty acid methyl esters)-type 4 biodiesel fuel (BDF). Although hydrogenated biodiesel (HBD) is anticipated as a new diesel 5 fuel, the environmental performance of HBD and its utilization system have not been 6 adequately clarified. Especially when waste cooking oil is used as feedstock, not only biofuel 7 production but also the treatment of waste cooking oil is an important function for society. A 8 life cycle assessment (LCA), including uncertainty analysis, was conducted to determine the 9 environmental benefits (global warming, fossil fuel consumption, urban air pollution, and 10 acidification) of HBD produced from waste cooking oil via catalytic cracking and 11 hydrogenation, compared with fossil-derived diesel fuel or FAME-type BDF. Combined functional unit including "treatment of waste cooking oil" and "running diesel vehicle for household waste collection" was established in the context of Kyoto city, Japan. The calculation utilized characterization, damage, and integration factors identified by LIME2, which was based on an endpoint modeling method. The results show that if diesel vehicles that comply with the new Japanese long-term emissions gas standard are commonly used in the future, the benefit of FAME-type BDF will be relatively limited. Furthermore, the scenario that introduced HBD was most effective in reducing total environmental impact, meaning that a shift from FAME-type BDF to HBD would be more beneficial.

\section{Keywords}

22 Waste-to-fuel, Biodiesel fuel (BDF), Hydrogenated biodiesel (HBD), Waste cooking oil, Catalytic cracking method, Life cycle assessment (LCA) 


\section{Introduction}

To develop a low-carbon society, it is important to promote the production of biofuels such as biodiesel fuel (BDF). Biofuels are produced worldwide: Biofuel consumption in road transport accounted for 1.3 Mboe/day (million barrels of oil equivalent per day) as of 2011, and is expected to increase to $4.1 \mathrm{Mboe} /$ day in 2035, an increase from 3\% of road transport fuel demand in 2011 to $8 \%$ in 2035. Of this, biodiesel consumption accounted for 0.4 Mboe/day and is estimated to be 1.1 Mboe in 2035 (IEA, 2013). The fuels that are currently under development utilize non-food feedstock, including waste (Naik et al., 2010; Sims et al., 2010; Takamizawa et al., 2013). Such fuels are thought to be more environmentally desirable, because biofuels derived from food crops such as soybeans are associated with a number of problems: competition with food agriculture for land and water use, and widely varying assessments of net greenhouse gas (GHG) reductions once land-use change is taken into account (Fargione et al., 2008; Searchinger et al., 2008).

In Kyoto city, Japan, waste cooking oil has been collected from households since 1998, and used to produce BDF since 2004. The BDF production facility operated by Kyoto city has a capacity of $5 \mathrm{~kL} /$ day $(1,500 \mathrm{~kL} / \mathrm{yr})$, and is the largest facility managed by a local government in Japan. The alkali catalysis method is commonly used to convert waste cooking oil to BDF, which consists of fatty acid methyl esters (FAME) (Meher, 2006; Salvo, 2012). As of fiscal year (FY) 2012, approximately 1,300 kL of FAME-type BDF has been produced annually from waste cooking oil (approximately $196 \mathrm{~kL}$ from households and 1,110 kL from businesses). Considering that the generation of waste cooking oil from households was estimated to be approximately 1,140 kL within Kyoto city, this represents a collection rate of $17 \%$ waste cooking oil from households for BDF production. The produced BDF has been used as fuel for city buses (B20) and household waste collection vehicles (B100) within Kyoto city.

From the standpoint of air pollution, there has been an increasing focus globally on the control of gas emissions from diesel vehicles (EC, 2007). As shown in Table 1, Japan has also established and enforced gas emission standards that regulate pollutants such as $\mathrm{NO}_{\mathrm{x}}$ and particulate matter (PM) emissions in a number of stages (DELPHI, 2014). For instance, in the case of $\mathrm{NO}_{\mathrm{x}}$ emissions, the standard value for vehicles of gross weight more than 3.5 tons is $3.38 \mathrm{~g}-\mathrm{NO}_{\mathrm{x}} / \mathrm{kWh}$ for the new short-term emissions gas standard (2002-2004), 2.00 g- $\mathrm{NO}_{\mathrm{x}} / \mathrm{kWh}$ for the new long-term standard (2005-2008), and $0.700 \mathrm{~g}-\mathrm{NO}_{\mathrm{x}} / \mathrm{kWh}$ for the post new long-term standard (2009 onward). However, FAME-type BDF is occasionally problematic when used in diesel vehicles (Fukuda et al., 2008; WFCC, 2013). In particular, some technical problems have arisen in terms of the suitability of BDF for new-model diesel vehicles equipped with diesel particulate filters and $\mathrm{NO}_{\mathrm{x}}$ reduction devices after implementation of the new long-term emissions standard. 
These problems, which include the mixing of fuel with engine oil and the poor performance of $\mathrm{NO}_{\mathrm{x}}$ reduction devices, have become major impediments to BDF use. Therefore, there are some challenges involved in producing new diesel fuels. HVO (hydrotreating of vegetable oils) has been developed and commercially supplied to mainly EU regions. HVO is also known as renewable diesel or HDRD (hydrogenation derived renewable diesel) in the USA, and as HBD (hydrogenated biodiesel) in the Far East including Japan (Neste Oil, 2014). HVO consists mainly of paraffins and is free of aromatics, oxygen, and sulfur. HVO generally shows higher cetane index and higher oxidation stabilities compared to FAME-type BDF (Bezergianni et al., 2013). HVO can be applied not only to vegetable oil but also to animal fats. Therefore, the HVO production method is expected to contribute to the expanding feedstock of BDF and resulting increases in fuel supplies. Neste Oil is the world's largest producer of HVO, which it supplies under the brand name "NExBTL.” Its production capacity is approximately 2 million ton/yr from four facilities. HVO is made by hydrotreatment of vegetable oils and animal fats, but additionally, waste and residues such as waste animal fat accounted for over half of feedstocks (Neste Oil, 2013). The OPTIBIO project operated for 3.5 years, between autumn 2007 and December 2010, to demonstrate the use of NExBTL for city buses in Helsinki. The project confirmed that HVO can replace fossil-derived diesel without any modifications to the vehicles or refueling system (Nylund et al., 2011). The Worldwide Fuel Charter (WWFC) now evaluates HVO as being highly suited as a blendstock for diesel fuel (WWFC, 2013).

HVO has been also developed in Japan, where it is often called HBD. Attention has been given to the production method, namely catalytic cracking and hydrogenation (Tani et al., 2011a, 2011b), and a three-year demonstration project for this new method, involving Kyoto city, ASTEM, and other companies, was operational between April 2012 and March 2015 (ASTEM, 2013; Kakuta, 2014; Takasuga, 2014). Unlike the general methods, the catalytic cracking process promotes decarbonization, which has the notable benefit of reducing the consumption of energy and $\mathrm{H}_{2}$. Hydrogenation after cracking requires normal pressure and temperature conditions (1.0 $\mathrm{MPaG}$ at $150^{\circ} \mathrm{C}$ ) and less $\mathrm{H}_{2}$, whereas direct hydrogenation requires high pressure and temperature (4-6 MPaG at $300-350^{\circ} \mathrm{C}$ ) and consumes 10 times the amount of $\mathrm{H}_{2}$. Therefore, hydrogenation after cracking is suitable for small- and mid-sized production facilities that utilize regional feedstocks such as waste cooking oil. The produced HBD has similar characteristics to those of diesel fuel, including calorific content and boiling point. The characteristics of some fuels, including HBD produced in the demonstration project at Kyoto city (ASTEM, 2013), are summarized in the electronic supplementary material. 
A life cycle assessment (LCA) was performed to evaluate the effectiveness of BDF use in reducing negative environmental impacts. Liang et al. (2013) quantitatively showed that feedstocks had different environmental performances by comparing seven feedstocks including waste cooking oil. Dufour et al. (2012) used LCA to evaluate six environmental impacts for four types of free fatty acid-rich wastes (used cooking oil, animal fats, sewage sludges), and concluded that biodiesel fuel from used cooking oil potentially achieved the most favorable environmental performance. On the other hand, when waste cooking oil was used for BDF production, the treatment (BDF production) method was also an important factor in environmental performance (Morais, 2010; Varanda, 2011). The environmental performance of HBD and its utilization system has not been adequately clarified. Garraín et al. (2014) showed that HBD blend diesel (13\% blend) from soybean oil could reduce fossil fuel consumption by $2 \%$ and GHG emissions by $9 \%$ at well-to-tank stage compared with FAME blend diesel. Neste Oil (2014) estimated that the GHG reduction effects of NExBTL compared with fossil-derived diesel were $47 \%$, 49\%, and $91 \%$ for palm oil, rapeseed oil, and animal fat feedstocks, respectively; and, by conducting exhaust gas emission tests, showed that emissions of PM were reduced by approximately 30-40\%. Evaluating exhaust gas emissions such as $\mathrm{NO}_{\mathrm{x}}$ and $\mathrm{PM}$ from HBD production and its utilization system by means of a life cycle approach is also necessary to determine environmental performance compared with the FAME-type BDF that is generally used. Arvidsson et al. (2011) conducted an LCA of HBD production from rapeseed oil, palm oil, and Jatropha considering four environmental impacts: fossil fuel consumption, global warming, acidification, and eutrophication. The functional unit of the analysis focused on fuel supply ( $1 \mathrm{kWh}$ of energy output). However, biofuel production and the treatment of waste cooking oil are important functions for society, especially when waste cooking oil is used as feedstock.

The purpose of this study was to clarify the effects of HBD on reducing environmental impacts compared with fossil-derived diesel fuel, or FAME-type BDF. An LCA including characterization, damage assessment, integration assessment, and uncertainty analysis was conducted to evaluate a number of environmental impacts including global warming and air pollution.

\section{Materials and methods}

\subsection{Functional unit and system boundary}

Table 2 shows the characteristics of the waste cooking oil considered in this study. Combined functional unit including "treatment of waste cooking oil" and "running diesel vehicle for household waste collection" was established. The first functional unit was assumed to be the treatment of 1,142 kL/yr and 1,108 kL/yr of waste cooking oil from households and businesses, respectively. The second functional unit assumed that $41.1 \mathrm{TJ}$ of 
diesel fuel (fossil-derived diesel fuel, FAME-type BDF, and HBD) was consumed by diesel vehicles used to collect household waste within Kyoto city. Both amounts reflected the actual situation in Kyoto city as of FY2012. Only waste cooking oil was considered as feedstock, although animal fats could be also used to produce HBD.

The system boundary included the collection of waste cooking oil, treatment or recycling (BDF production), and fossil-derived diesel fuel and/or BDF consumption of a diesel-powered collection vehicle. With regard to fossil fuel consumption, the system boundary considered the stages from raw material extraction to final use (combustion), and associated environmental impacts were allocated to the process that consumed the fossil fuel.

\section{Table 2}

\subsection{Environmental impacts}

LIME1, a Japanese life-cycle impact assessment method, was developed for the first term (1998-2003) of a national LCA project, whereas LIME2 was developed for the second term (2003-2006) (JLCA, 2012). LIME2 was based on an endpoint modeling method, and considered environmental conditions, such as weather and population density, in Japan such as weather and population density. Therefore, LIME2 is mainly applied in Japan (European Commission, 2010).

LIME2 comprises 19 category endpoints that are connected by 15 environmental impact categories (JLCA, 2012). These environmental impact categories are assessed by integration, following characterization and damage assessment. Characterization is the first step, in which potential environmental impacts are assessed for each impact category. It is possible to compare or integrate the impacts of two or more environmentally damaging substances on the specific impact category. Damage assessment is the second step in assessing the amount of damage that can occur for each object of protection. In LIME, four items were defined as objects of protection: human health, social assets, biodiversity, and primary production. The Disability Adjusted Life Year (DALY), which is used internationally for health statistics, was defined as the damage index for human health. An economic index in Japan, that can comprehensively measure the impact on various components (agricultural products, forests, marine products, and resources), was defined as the damage index for social assets. EINES, which was originally based on the methodology for assessing extinction risk in the field of conservation ecology, was defined as the damage index for biodiversity. Net primary production (NPP), which is widely used as an index of ecosystem richness in the fields of biology and landscape architecture, was defined as the damage index for primary production. Integration is the final step, in which the results of the four objects of protection are converted into a single index by means of weighting factors. In LIME2, conjoint, analysis was adopted for weighting the area of protection. 
The considered environmental impacts in this study were fossil fuel consumption, global warming, urban area air pollution, and acidification. The calculation utilized characterization, damage, and integration factors identified by LIME2. These factors were retrieved from the website of the Life Cycle Assessment Society of Japan (JLCA). The impact categories and their objects are listed in Table 3. With regards to global warming, $\mathrm{CO}_{2}$ emissions derived from biomass are regarded as carbon-neutral, and were therefore excluded from the calculation. Table 4 shows a list of impact categories and corresponding damage factors.

\section{Table 3}

Table 4

\subsection{Scenario setting}

The scenarios in this study are listed in Table 5. As a base scenario, all waste cooking oil from households and businesses was assumed to be collected with mixed waste and then incinerated, while diesel fuel was used to operate household waste collection vehicles. With regard to a baseline scenario, two sub-scenarios were considered, based on the diesel vehicle types covered by the Japanese emission gas standard: one where diesel vehicles complied with the new short-term emissions gas standard (scenario S1-short), and the other where diesel vehicles complied with the new long-term emissions gas standard (scenario S1-long). S1-short is the scenario that reflects the general, current situation in Japan, while S1-long reflects the future exhaust gas control situation.

For the BDF utilization scenarios, $196 \mathrm{~kL} / \mathrm{yr}$ of waste cooking oil from households $(17 \%$ as collection efficiency) and 1,108 kL/yr from businesses were collected separately, from which BDF was produced by the alkali catalysis method (scenario S2-short), or the catalytic cracking and hydrogenation method (scenario S3-long). The remaining $947 \mathrm{~kL} / \mathrm{yr}$ from households was incinerated with mixed waste. Because of the above-mentioned technical problems for diesel particulate filters required for the long-term emissions gas standard, it was assumed that FAME-type BDF was used only for diesel vehicles that complied with the new short-term emissions gas standard (S2-short). It could be said that S2-short reflects the current situation in Kyoto city; on the other hand, HBD could be used for diesel vehicles that comply with both the new short-term and the new long-term emission gas standards. However, HBD was used for diesel vehicles that only complied with the new long-term emissions gas standard in S3-long, in order to evaluate the more desirable HBD utilization system.

Fig. 1 shows the system flow of each scenario, and each process setting is explained in section 2.4 .

\section{Table 5}




\subsection{Unit processes and data collection}

Important parameters used in this study are listed in Table 6, and each process is briefly introduced below. The later sections also discuss the uncertainties that were considered for some parameters.

\subsubsection{Collection}

A grid city model (Ishikawa, 1996) was used for calculating the annual collection distance and diesel fuel consumption. Direct emissions of $\mathrm{CO}_{2}$ and $\mathrm{CH}_{4}, \mathrm{~N}_{2} \mathrm{O}, \mathrm{SO}_{\mathrm{x}}, \mathrm{NO}_{\mathrm{x}}, \mathrm{PM}_{2.5}$, and $\mathrm{PM}_{10}$ from household waste collection vehicles were then estimated.

In S1-short and S1-long, all waste cooking oil from households was assumed to be collected twice a week with mixed waste, and the weight of waste cooking oil accounted for $0.50 \%$ of household waste. Therefore, the estimated amount of diesel fuel consumption was allocated based on weight. In S2-short and S3-long, $947 \mathrm{~kL} / \mathrm{yr}$ of waste cooking oil, which was failed to be collected separately, was also assumed to be collected with mixed waste.

In S2-short and S3-long, FAME-type and HBD could both be used to power household waste collection vehicles. However, this benefit was not included in the "collection" process, but rather in the "running household waste collection vehicle" process, as will be explained later. Only fossil-derived diesel fuel was consumed in this process.

\subsubsection{Incineration with energy recovery}

In this process, it was assumed that waste cooking oil and waste glycerin, which was co-generated by the FAME-type BDF production process using an alkali-catalyzed method (S2-short), were incinerated with household waste in the incineration facility within Kyoto city. Direct emissions of $\mathrm{CH}_{4}, \mathrm{~N}_{2} \mathrm{O}, \mathrm{SO}_{\mathrm{x}}, \mathrm{NO}_{\mathrm{x}}, \mathrm{PM}_{2.5}$, and $\mathrm{PM}_{10}$ from waste combustion were calculated. $\mathrm{CO}_{2}$ emissions from fossil-derived carbon were also counted because waste glycerin contained unreacted methanol. It was assumed that there was no residue, as nearly all the waste cooking oil was combustible.

Electricity was considered as energy consumption and calculated using an empirical formula based on household waste composition (NIES, 2008). At the same time, an electricity production facility with an efficiency of $15 \%$ was assumed to be associated with the incineration facility. Both consumption and substituted electricity refer to commercial electricity from utility companies. The weighted average emission factors for 10 companies in Japan were used in this analysis.

\subsubsection{FAME-type BDF production by alkali catalysis method}


Waste cooking oil and methanol were used for BDF production by an alkali-catalyzed method. Electricity and paraffin oil were considered as energy consumption. Inventory data were obtained from the BDF production facility in Kyoto city. It should be noted that fossil-derived carbon in the produced FAME-type BDF accounted for approximately $7.0 \%$ of the total carbon content because methanol, which was produced from natural gas, was used for FAME-type BDF. Co-generated waste glycerin contained $\mathrm{KOH}$ as a catalyst, unreacted methanol, and waste cooking oil. Waste glycerin was assumed to be treated during incineration with the energy recovery process mentioned previously. The characteristics of waste glycerin are presented in the electronic supplementary material.

\subsubsection{HBD production by catalytic cracking and hydrogenation method}

The HBD production process can be described as follows: Firstly, waste cooking oil was degraded at around $400-500^{\circ} \mathrm{C}$, and the organic acids contained in the decomposed oil were decomposed for conversion into hydrocarbons at the reactor. Offgas consisting of $\mathrm{CO}_{2}, \mathrm{CO}$, $\mathrm{H}_{2}, \mathrm{CH}_{4}$, and other hydrocarbons, was also produced at this stage. Secondly, the produced hydrocarbons were separated into high-, intermediate- (biodiesel), and low-boiling-point oils using two condensers. Thirdly, a minor amount of acid contained in the biodiesel was removed, and the biodiesel was refined for long-term stability. Finally, the refined biodiesel was hydrogenated using $\mathrm{H}_{2}$ at $150-250^{\circ} \mathrm{C}$ in order to improve stability for oxidation and heat. This study refers to hydrogenated diesel fuel as HBD. In total, 90.7\% of the input waste cooking oil on an energy basis could be recovered in the form of HBD, other oils, and offgas. The HBD showed an energy yield of 52.8\%, which was lower than that of FAME-type BDF.

Inventory data were obtained from a demonstration project by ASTEM. Electricity was considered as energy consumption. Offgas, and high- and low-boiling-point oils, which were co-generated in this process, were combusted for heating supply. Of these types, only the low-boiling-point oil could be exported from the facility as surplus energy after heating. Therefore, it was assumed that naphtha was substituted by surplus low-boiling-point oil on a heating value basis.

\subsubsection{Diesel fuel production}

The production of diesel fuel as commercially used in Japan was assumed in this process. Inventory data provided by JLCA (JLCA, 2012) were used to calculate $\mathrm{CO}_{2}, \mathrm{SO}_{2}, \mathrm{NO}_{2}$, and $\mathrm{PM}_{10}$ emissions. All PM emissions were regarded as $\mathrm{PM}_{10}$ in this process because of a lack of data.

\subsubsection{Running household waste collection vehicle}

Direct emissions of $\mathrm{CO}_{2}, \mathrm{SO}_{\mathrm{x}}, \mathrm{NO}_{\mathrm{x}}, \mathrm{PM}_{2.5}$, and $\mathrm{PM}_{10}$ were calculated in this process. $\mathrm{CO}_{2}$ 
and $\mathrm{SO}_{\mathrm{x}}$ emissions were calculated using the elemental composition of the fuels. The other emission factors (EFs) were assumed to differ according to the types of diesel vehicles covered by the Japanese emission gas standards: the new short-term emissions gas standard (S1-short, S2-short), and the new long-term emissions gas standard (scenario S1-long, S3-long). The type of fuel also affected the EFs. Therefore, the results of emission testing from the vehicles currently used for household waste collection by Kyoto city, which considered the type of fuel, were adopted as EFs (Kyoto city) after converting the data from $\mathrm{g} / \mathrm{kWh}$ to $\mathrm{g} / \mathrm{L}$. The proportions of $\mathrm{PM}_{10}$ and $\mathrm{PM}_{2.5}$ were based on a previous study by Motoshita (2008), since these data were absent from the emission testing in Kyoto city. However, it was assumed that there was no difference between EFs in HBD and those in diesel fuel, because there were no actual data for HBD. The demonstration project by ASTEM plans to include a fleet running test.

\section{Results and Discussion}

\subsection{Characterization}

The estimated characterization results are shown in Fig. 2. With regard to global warming and fossil fuel consumption, there are no differences between S1-short and S1-long. In every scenario, $\mathrm{CO}_{2}$ emission was the dominant contributor to global warming compared with other emissions, $\mathrm{CH}_{4}$, and $\mathrm{N}_{2} \mathrm{O}$. The running household waste collection vehicle process contributed to increases in GHG emissions in S1 and S3-long, because the process consumed fossil-derived diesel fuel. GHG emissions from the incineration process in S2-short exceeded those in S1 and S3-long, because the production of FATE-type BDF in S2-short incinerated waste glycerin containing carbon from fossil-derived methanol. Nevertheless, net total GHG emissions from S2-short showed a negative value ( $\left.-150 \mathrm{t}-\mathrm{CO}_{2} \mathrm{eq} / \mathrm{yr}\right)$, indicating that the use of waste cooking oil for FAME-type BDF could help reduce net GHG emissions. On the contrary, in S1 and S3-long, net total GHG emissions were estimated to be $1561 \mathrm{t}-\mathrm{CO}_{2} \mathrm{eq} / \mathrm{yr}$ and $547 \mathrm{t}-\mathrm{CO}_{2} \mathrm{eq} / \mathrm{yr}$ respectively. GHG reduction effects from energy recovery in incineration and substituted naphtha were not sufficiently large to cancel out the GHG emissions, which were mainly derived from the running of household waste collection vehicles. GHG emissions in S3-long were reduced by 65\% compared with S1, which used fossil-derived diesel. On the other hand, RED (European Commission, 2009: Directive 2009/28/EC) introduced GHG reduction effects of $47 \%$ and $65 \%$ by HVO from rapeseed oil and sunflower, respectively. NExBTL from palm oil, and rapeseed oil reduced GHG emissions by $47 \%$ and 49\%, respectively, compared with fossil-derived diesel (Neste Oil, 2014). It was implied that HBD production from waste cooking oil and its utilization system in this study could achieve equivalent GHG reduction, despite the different system boundaries employed by the two 
studies.

Fossil fuel consumption in S2-short and S3-long could be reduced by $120 \%$ and $58 \%$, as compared with S1. The FAME-type BDF production process consumed more fossil fuels than HBD, because the latter could use by-products such as offgas for heating supply. Surplus low-boiling-point oil also contributed to reductions in the net consumption of fossil fuel.

Urban area air pollution and acidification showed similar results, which indicated that the type of diesel vehicle covered by the Japanese emission gas standard had the largest impact on urban area air pollution. Although $\mathrm{NO}_{\mathrm{x}}$ emission was the dominant contributor to urban area air pollution and acidification in every scenario, the emission amounts differed by the type of diesel vehicle. In S1-short and S2-short, $\mathrm{NO}_{\mathrm{x}}$ emissions from household waste collection vehicles that complied with the new short-term emissions gas standard were dominant. On the contrary, it was apparent that a shift to vehicle types that complied with the new long-term emissions gas standard could dramatically reduce $\mathrm{NO}_{\mathrm{x}}$ emissions. As net results, urban area air pollution and acidification in S1-long were decreased by $90 \%$ and $78 \%$ respectively, compared with S1-short. Energy recovery during incineration also contributed to reducing emissions of air pollutants especially $\mathrm{SO}_{\mathrm{x}}$, which was one factor that made S1-short and S1-long superior to S2-short and S3-long, respectively, in terms of urban area air pollution and acidification. In S3-long, reductions of $76 \%$ in urban area air pollution and $75 \%$ in acidification were achieved compared with S1-short.

\section{Fig. 2}

\subsection{Damage assessment}

Fig. 3 shows the estimated damage for the four endpoints (in all endpoints, lower values indicate less damage). $\mathrm{NO}_{\mathrm{x}}$ emissions from household waste collection vehicles affected human health. $\mathrm{NO}_{\mathrm{x}}$ emissions accounted for $42 \%$ and $67 \%$ of overall damage in the S1-short and S2-short scenarios, compared with $18 \%$ and $34 \%$ in S1-long and S3-long. $\mathrm{PM}_{2.5}$ emission from incineration also affected human health in all scenarios. $\mathrm{SO}_{\mathrm{x}}$ emissions showed negative value as a result of the substitution effect of the electricity production in incineration with energy recovery process, although their effect was small. In S2-short, $\mathrm{CO}_{2}$ emission also showed negative value because this scenario consumed no fossil-derived diesel to operate the household waste collection vehicles. These results imply that, as a treatment for waste cooking oil, a shift from incineration to BDF production contributes to protecting human health, mainly as a result of avoiding the emission of $\mathrm{PM}_{2.5}$.

Crude oil extraction for diesel production, and subsequent emission of $\mathrm{NO}_{\mathrm{x}}$ by operating household waste collection vehicles, were the dominant sources of damage to social assets. In S2-short, $\mathrm{NO}_{\mathrm{x}}$ emissions accounted for $92 \%$ of the total impact on social assets. The result indicated that shifting from incineration of waste cooking oil as in S1-short to FAME-type 
360

361

362

363

364

365

366

367

368

369

370

371

372

373

374

375

376

377

378

379

380

381

382

383

384

385

386

387

388

389

390

391

392

393

394

395

396

BDF production as in S2-short had more benefits than shifting from diesel vehicles compliant with the new short-term gas standard (such as S1-short) to those compliant with the new long-term gas standard (such as S1-long).

Biodiversity was affected only by coal consumption. Electricity produced via incineration with energy recovery process was the dominant factor even if the electricity consumed in the other processes was considered.

There were two major factors in primary production: one was the coal reduction effect achieved by electricity substitution at incineration with energy recovery process, and the other was $\mathrm{NO}_{\mathrm{x}}$ emission associated with operating household waste collection vehicles. Because S1-long could benefit from both these factors, the scenario showed the least impact on biodiversity.

The results are also summarized in Table 7. Comparing the four scenarios, S3-long showed the best environmental performance for human health and social assets; S1-short and S1-long were the best for biodiversity. S1-long also showed the best performance for net primary production. It is important to evaluate these four endpoints in combination, which is discussed in the next section.

Fig. 3

Table 7

\subsection{Integration}

The estimated integration results from each scenario are shown in Fig. 4. Compared with S1-short, S1-long could reduce urban area air pollution and acidification, whereas S2-short could reduce global warming and fossil fuel consumption. In terms of the net results, the use of FAME-type BDFs in S2-short could reduce environmental impacts by $42 \%$ compared with S1-short, while S1-long also reduced environmental impact by $42 \%$.

These results imply that if diesel vehicles compliant with the new long-term emissions gas standard are commonly used in the future, as was considered in S1-long, the benefit of using FAME-type BDF (S2-short) will apparently be relatively low. This is because FAME-type BDF cannot be used for vehicles that comply with the long-term emissions gas standard. However, if HBD is produced using the catalytic cracking and hydrogenation method, environmental impacts could be reduced by $71 \%$ and 50\% compared with those in S1-short and S1-long, respectively. Therefore, it was concluded that a shift from FAME-type BDFs to HBD in the future would be effective in reducing environmental impacts, including not only global warming but also fossil fuel consumption, urban air pollution, and acidification.

Fig. 4 


\subsection{Uncertainty analysis}

Some parameters include uncertainties, which must therefore be considered in the LCA. Clavreul et al. (2012) reviewed and categorized uncertainties in LCAs for waste management systems into three uncertainties using the framework introduced by Huijbregts et al. (1998), one of which is parameter uncertainty. In this study, uncertainty analysis was conducted for the four parameters in Table 8, which strongly influenced the results.

Electricity was the largest energy source, followed by diesel fuel. The range was taken as the minimum to maximum EFs of electricity consumption during 5 years (FY2008-2012). The default value was accordingly the maximum value in 5 years.

The efficiency of energy recovery is one of the fundamental factors for determining the environmental performance of incineration processes (Gentil et al., 2010). The limitations imposed by technical issues or treatment capacity mean that an incineration facility might not include an electricity production facility. In Japan, approximately 310 of 1,100 incineration facilities include electricity production facilities, and electricity production efficiency was 11.7\% as of FY2011 (MOE, 2013a). The Japanese Ministry of the Environment (MOE, 2013b) aims to achieve $21 \%$ average electricity production efficiency for incineration facilities that will be constructed during FY2013-2017. Therefore, 0\% (no electricity production facility) and 20\% were considered as minimum and maximum values.

The EF of $\mathrm{NO}_{\mathrm{x}}$ derived from exhaust gas from household waste collection vehicles depends not only on fuel type but various factors: carrying capacity, running speed, etc. The actual EF of HBD produced by the catalytic cracking and hydrogenation method will be clarified via the proposed fleet running test during the demonstration project by ASTEM. Therefore, to establish the tendency of uncertainty derived from the EF, the minimum and maximum EFs of $\mathrm{NO}_{\mathrm{x}}$ were determined by comparing the average value reported in some previous studies (JPEC, 2005; Koyano et al., 2009). Due to lack of data, it was assumed that the EF of HBD equaled that of diesel fuel.

The EFs of $\mathrm{PM}_{2.5}$ and $\mathrm{NO}_{\mathrm{x}}$ at an incineration facility depend on the flu gas treatment system installed at the facility (Møller et al., 2011; Shiota et al., 2011). The EF range of $\mathrm{PM}_{2.5}$ was determined using the range of four facilities (Shiota et al., 2011). The EF of $\mathrm{NO}_{\mathrm{x}}$ was not included in uncertainty analysis because $\mathrm{NO}_{\mathrm{x}}$ emissions during incineration had smaller impacts compared with other emissions.

\section{Table 8}

The results are shown in Fig. 5 and Fig. 6. With regard to the EF of electricity consumption, $\mathrm{CO}_{2}$ emission factor affected global warming, human health, and integration, whereas the other EFs $\left(\mathrm{NO}_{\mathrm{x}}\right.$ and $\mathrm{SO}_{\mathrm{x}}$ ) had smaller effect. The EFs had significant impact on the ranking between S1-long and S2-short. 
Electricity production efficiency had a large effect on all impact categories except acidification, and on all endpoints and the integration result. It had larger impact on the results for S1-short and S1-long than in the other scenarios because there was greater use of incineration. It was also indicated that the inclusion of an electricity production facility contributed to reducing environmental impacts in all scenarios. In the absence of an electricity production facility, the integration results in each scenario increased by $30 \%, 53 \%, 28 \%$, and $45 \%$, respectively.

The EF of exhaust gas from household waste collection vehicles compliant with the new long-term standard had a bigger impact on the results than vehicles compliant with the new short-term standard. This was because the range (3.32-10.1 g/L) was wider in S1-long and S3-long than those in S1-short (16.2-17.3 g/L) and S2-short (16.2-18.3 g/L).

The EFs of $\mathrm{PM}_{2.5}$ in incineration facilities tended to give wider ranges for the integration results in all scenarios compared with the other three parameters used in the uncertainty analysis. This was because the EF had a large effect on human health. It should be noted that the EF might include sufficient uncertainty to reverse the ranking between the S1-long and S2-short scenarios.

Electricity production efficiency and EF of $\mathrm{PM}_{2.5}$ at incineration facility had larger impacts than the other parameters on result of integration. Therefore, the treatment of waste cooking oil is the significant factor in determining the results. The results of uncertainty analysis indicated that ranking between S1-long and S2-short might be reversed. However, it could be also said that S1-short, which reflects the current situation in Japan, was the worst scenario, and that S3-long was the desired scenario.

This study focused on four parameters for uncertainty analysis. However, there remain further uncertainties, as follows:

- Actual EFs of exhaust gas from household waste collection vehicles using HBD are currently unknown. Exhaust gas sampling and analysis will therefore be required during the proposed fleet running test.

- The exhaust gas emission standard has been getting stricter than that in the new long-term standard in Japan. Therefore, when those diesel vehicles currently in use are exchanged for vehicles using HBD that meet stricter performance criteria than the new long-term standard, further reduction of the environmental impacts will be possible. On the other hand, blending FAME-type BDF with fossil-derived diesel fuel such as B5 is one solution to extend the future use of diesel vehicles that comply with the new short-term standard. However, in such case, the environmental impacts associated with the exhaust gas emissions will not be reduced.

- Due to salting during cooking, waste cooking oil might contain higher $\mathrm{Cl}$ content than other feedstock such as unused vegetable oil and animal fats. $\mathrm{Cl}$ contents in both waste 
cooking oil and in cracking oil before hydrogenation are less than $10 \mathrm{ppm}$. Because the $\mathrm{Cl}$ content could contribute to acidification, more detailed $\mathrm{Cl}$ behavior will also need to be considered in future studies.

Fig. 5

Fig. 6

\section{Conclusions}

There is a worldwide trend towards stricter control of exhaust emissions from diesel vehicles. Certain technical issues have become major impediments to the use of FAME-type BDF in diesel vehicles that comply with the new long-term emissions standard. The purpose of this study was to clarify the reduction effects of HBD produced by the catalytic cracking and hydrogenation method on environmental impacts, as compared with fossil-derived diesel fuel or FAME-type BDF. An LCA including uncertainty analysis was conducted to evaluate four environmental impacts: global warming, fossil fuel consumption, urban area air pollution, and acidification. Both the operation of diesel vehicles and the treatment of waste cooking oil were also considered as functional units.

Our conclusions are as follows:

- If diesel vehicles that comply with the new long-term emissions gas standard are commonly used in the future, the benefit of using FAME-type BDF will be relatively modest.

- The results including uncertainty analysis indicate that S1-short, which reflects the current situation in Japan, was the least optimal scenario, and that S3-long, which introduced HBD, was most effective in terms of reducing environmental impact.

- Therefore, a shift from FAME-type BDF to HBD in the future would be more effective in reducing total environmental impacts comprising not only global warming but also fossil fuel consumption, urban air pollution, and acidification.

\section{Abbreviations list}

BDF : biodiesel fuel

$$
\text { DALY : disability-adjusted life year }
$$

DAP : deposition-oriented acidification potential

EINES : expected increase in number of extinct species

FAME : fatty acid methyl esters

FY : fiscal year

\section{GHG : greenhouse gas}

GWP : global warming potential

HBD : hydrogenated biodiesel 
508 HDRD : hydrogenation derived renewable diesel

$509 \quad$ HVO : hydrotreating of vegetable oils

510 LCA : life cycle assessment

$511 \quad$ NPP : net primary productivity

$512 \quad$ PM : particulate matter

513 UAF : urban air pollution characterization factor

\section{Acknowledgements}

This research was supported by the Low-Carbon Technology Research and Development program of the Ministry of the Environment, Japan. The demonstration project entitled "R\&D towards the utilization of 2nd generation biodiesel suitable for vehicles” between FY2012FY2014 was managed by ASTEM (Advanced Scientific Technology \& Management Research, Institute of KYOTO); City of Kyoto; and research partners: Toyota Motor Corporation; Japan Organics Recycling Association. The author would like to express gratitude for their cooperation.

523

\section{REFERENCES}

Arvidsson R., Persson S., Fröling M., Svanström M., 2011. Life cycle assessment of hydrotreated vegetable oil from rape, oil palm. Journal of Cleaner Production, 19 (2-3), 129-137.

ASTEM, 2013. Report on R\&D towards the utilization of 2nd generation biodiesel suitable for vehicles. Kyoto, Japan (in Japanese).

Bezergianni S., Dimitriadis A., 2013. Comparison between types of renewable diesel. Renewable and Sustainable Energy Reviews, 21, 110-116.

Clavreul J., Guyonnet D., Christensen T. H., 2012. Quantifying uncertainty in LCA-modelling of waste management systems. Waste Management, 32, 2482-2495.

DELPHI, 2014. Worldwide Emissions Standards Heavy Duty and Off-Highway Vehicles 2014-2015.

Dufour J., Iribarren D., 2012. Life cycle assessment of biodiesel from free fatty acid-rich wastes. Renewable Energy, 38, 155-162.

European Commission, 2007. Regulation (EC) No. 715/2007 of the European Parliament and of the Council of 20 June 2007 on type approval of motor vehicles with respect to emissions from light passenger and commercial vehicles (Euro 5 and Euro 6) and on access to vehicle repair and maintenance information.

European Commission, 2009. Directive 2009/28/EC of the European Parliament and of the Council on the promotion of the use of energy from renewable sources and amending and subsequently repealing Directives 2001/77/EC and 2003/30/EC. 
European Commission, Joint Research Centre, Institute for Environment and Sustainability, 2010. ILCD Handbook: Analysis of existing Environmental Impact Assessment methodologies for use in Life Cycle Assessment (LCA).

Fargione J., Hill J., Tilman D., Polasky S., Hawthorne P., 2008. Land clearing and the biofuel carbon debt. Science Express, 319 (5867), 1235-1238.

Fukuda K., Kohakura M., Kaneko T., Furui K., Tsuchibashi K., Hasegawa T., Saitou K., Baba H., Shibuya M., Nakamura O., Okada M., Hosono K., Hirata K., Kawatani T., Sugiyama G., 2008. Impact study of high biodiesel blends on performance of exhaust aftertreatment systems. SAE Technical Paper 2008-01-2494.

Garraín D., Herrera I., Lechón Y., Lago C., 2014. Well-to-Tank environmental analysis of a renewable diesel fuel from vegetable oil through co-processing in a hydrotreatment unit. Biomass and Bioenergy, 63, 239-249.

Gentil E. C., Damgaard A., Hauschild M., Finnveden G., Eriksson O., Thorneloe S., Kaplan P. O., Barlaz M., Muller O., Matsui Y., Ii R., Christensen T. H., 2010. Models for waste life cycle assessment: Review of technical assumptions. Waste Management, 30 (12), 2636-2648.

Hirai Y., Murata M., Sakai S., Takatsuki H., 2001. Life cycle assessment on food waste management and recycling. Journal of Japan Society and Waste Management, 12 (5), 219-228 (in Japanese).

Huijbregts, M. A. J., 1998. Application of uncertainty and variability in LCA, Part I: A general framework for the analysis of uncertainty and variability in life cycle assessment. International Journal of Life Cycle Assessment, 3 (5), 273-280.

IEA, 2013. World energy outlook 2013. Chapter 6: Renewable energy outlook.

Ishikawa M., 1996. A logistics model for post-consumer waste recycling. Journal of Packaging Science and Technology, Japan, 5 (2), 119-130.

JLCA website. <http://lca-forum.org/database/impact/> (accessed February 2014) (in Japanese).

JLCA, 2012. LIME2 Life-cycle impact assessment method based on endpoint modeling summary. JLCA News English 2012. $<$ http://lca-forum.org/english/pdf/No12_Summary.pdf> (accessed May 2014).

JLCA, 2013. JLCA data base ver. $3<$ http://lca-forum.org/database/> (accessed February 2014) (in Japanese).

JPEC (Japan Petroleum Energy Center), 2005. Diesel WG report - Focusing on effects of sulfur on latest after-treatment devices, $4^{\text {th }}$ JCAP Conference, Tokyo, Japan.

Kakuta Y., Nakamura K., 2014. Basic test on technology for conversion to second-generation biodiesel fuel. Proceedings of the 3R International Scientific Conference on Material Cycles and Waste Management 2014, Kyoto, Japan. 
582

583

584

585

586

587

588

589

590

591

592

593

594

595

596

597

598

599

600

601

602

603

604

605

606

607

608

609

610

611

612

613

614

615

616

617

618

Koyano S., Kinoshita T., Yamazaki M., Yokota H., Okamura H., 2009. Exhaust-gas characteristics such as NOx from heavy duty diesel vehicles which met new long term regulation. Annual report of the Tokyo Metropolitan Institute for Environmental Protection, 101-106.

Liang S., Xu M., Zhang T., 2013. Life cycle assessment of biodiesel production in China. Bioresource Technology, 129, 72-77.

Meher L. C., Vidya Sagar D., Naik S. N., 2006. Technical aspects of biodiesel production by transesterification - A review. Renewable and Sustainable Energy Reviews, 10 (3), 248-268.

MOE, Japan, 2009. Guideline for the estimation and its report on greenhouse gas emission Ver. 2.4 (in Japanese).

MOE, Japan, 2013a. Annual report on the environment and the sound material-cycle society in Japan 2011 (in Japanese).

MOE, Japan, 2013b. Maintenance plan for waste treatment facilities in FY2013-2017 (in Japanese).

MOE, Japan greenhouse gas inventory office of Japan (GIO), CGER, NIES, 2012. National greenhouse gas inventory report of JAPAN. Ministry of the Environment, Japan. <http://www-gio.nies.go.jp/aboutghg/nir/2012/NIR-JPN-2012-v3.0E.pdf> (accessed February 2014).

Møller J., Munk B., Crillesen K., Christensen T. H., 2011. Life cycle assessment of selective non-catalytic reduction (SNCR) of nitrous oxides in a full-scale municipal solid waste incinerator. Waste Management, 31(6), 1184-1193.

Morais S., Mata T. M., Martins A. A., Pinto G. A., Costa C. A. V., 2010. Simulation and life cycle assessment of process design alternatives for biodiesel production from waste vegetable oils. Journal of Cleaner Production, 18 (13), 1251-1259.

Motoshita M., Itsubo N., Inaba A., 2008. Uncertainty analysis for LCA of passenger cars as a case study. Journal of Life Cycle Assessment, Japan, 4 (3), 260-269 (in Japanese).

Naik S. N., Goud V. V., Rout P. K., Dalai A. K., 2010. Production of first and second generation biofuels: A comprehensive review. Renewable and Sustainable Energy Reviews, 14 (2), 578-597.

Neste Oil, 2013. Neste Oil's annual report 2013.

Neste Oil, 2014. Hydrotreated vegetable oil (HVO) - premium renewable biofuel for diesel engines.

NIES, 2008. Technical development report of hydrogen production from biomass and biowaste. Tsukuba, Japan (in Japanese).

Nylund N. -O., Erkkilä K., Ahtiainen M., Murtonen T., Saikkonen P., Amberla A., Aatola H., 2011. Optimized usage of NExBTL renewable diesel fuel OPTIBIO. VTT Tiedotteita - 
619

620

621

622

623

624

625

626

627

628

629

630

631

632

633

634

635

636

637

638

639

640

641

642

643

644

645

646

647

648

Valtion Teknillinen Tutkimuskeskus 2604.

Salvo B. L., Panwar N. L., 2012. Biodiesel resources and production technologies - A review. Renewable and Sustainable Energy Reviews, 16 (6), 3680-3689.

Searchinger T., Heimlich R., Houghton R. A., Dong F., Elobeid A., Fabiosa J., Tokgoz S., Hayes D., Yu T.-H., 2008. Use of U.S. croplands for biofuels increases greenhouse gases through emissions from land use change. Science, 319 (5867), 1238-1240.

Shiota K., Imai G., Takaoka M., Kimoto S., Matsui Y., Oshita K., Mizuno T., Morisawa S., 2011. The effect of countermeasures for dioxin removal on the emission of fine particles from municipal solid waste incinerators. Journal of Japan Society for Atmospheric Environment, 46 (4), 224-232 (in Japanese).

Sims R. E. H., Mabee W., Saddler J. N., Taylor M., 2010. An overview of second generation biofuel technologies. Bioresource Technology, 101 (6), 1570-1580.

Takamizawa K., Ishikawa E., Nakamura K., Futamura T., 2013. Bioethanol production from enzymatically saccharified lawn clippings from a golf course. Journal of Material Cycles and Waste Management, 15 (1), 16-24.

Takasuga T., Kuratani K., Matsushita M., Nakamura K., 2014. Detailed chemical analysis and evaluation of 2nd generation bio-diesel fuel. Proceedings of the 3R International Scientific Conference on Material Cycles and Waste Management 2014, Kyoto, Japan.

Tani H., Shimouchi M., Haga H., Fujimoto K., 2011a. Development of direct production process of diesel fuel from vegetable oils. Journal of the Japan Institute of Energy, 90, 466-470.

Tani H., Hasegawa T., Shimouchi M., Asami K. Fujimoto K., 2011b. Selective catalytic decarboxy-cracking of triglyceride to middle-distillate hydrocarbon. Catalysis Today, 164 (1), 410-414.

Varanda M. G., Pinto G., Martins F., 2011. Life cycle analysis of biodiesel production. Fuel Processing Technology, 92 (5), 1087-1094.

Worldwide Fuel Charter Committee, 2013. Worldwide fuel charter, Fifth edition.

Yasuda K., 1997. Greenhouse emissions from waste incineration in Japan. Journal of Japan Society and Waste Management, 8 (6), 432-437 (in Japanese). 
Table 1 Exhaust gas emission standards for heavy commercial vehicles in Japan

\begin{tabular}{|c|c|c|c|c|c|}
\hline Version of standard & Short-term & Long-term & $\begin{array}{c}\text { New } \\
\text { short-term }\end{array}$ & $\begin{array}{c}\text { New } \\
\text { long-term }\end{array}$ & $\begin{array}{l}\text { Post new } \\
\text { long-term }\end{array}$ \\
\hline Implementation date & 1994 & 1997 & 2003 & 2005 & 2009 \\
\hline Test mode & 13 mode & 13 mode & 13 mode & JC08 & JC08 \\
\hline \multicolumn{6}{|l|}{ Regulation value } \\
\hline $\mathrm{NO}_{\mathrm{x}}(\mathrm{g} / \mathrm{kWh})$ & 6.8 & 4.50 & 3.38 & 2.0 & 0.7 \\
\hline PM (g/kWh) & 0.96 & 0.25 & 0.18 & 0.027 & 0.010 \\
\hline $\mathrm{CO}(\mathrm{g} / \mathrm{kWh})$ & 9.20 & 7.40 & 2.22 & 2.22 & 2.22 \\
\hline HC, NMHC (g/kWh) & 3.80 & 2.90 & 0.87 & 0.17 & 0.17 \\
\hline
\end{tabular}

The heavy commercial vehicle category has a gross vehicle weight $>3.5$ tons $(>2.5$ tons before 2005).

Implementation dates refer to new vehicle models. 
Table 2 Characteristics of waste cooking oil

\begin{tabular}{lrl}
\hline Density & 0.92 & ton $/ \mathrm{kL}$ \\
Moisture content & 0.2 & $\mathrm{wt} \%$ \\
Lower heating value & 36.6 & $\mathrm{MJ} / \mathrm{kg}$ \\
Elemental composition & & \\
$\mathrm{C}$ & 78.1 & $\mathrm{wt} \%$ \\
$\mathrm{H}$ & 11.5 & $\mathrm{wt} \%$ \\
$\mathrm{O}$ & 9.8 & $\mathrm{wt} \%$ \\
$\mathrm{~S}$ & 2.2 & $\mathrm{ppm}$ \\
\hline
\end{tabular}


Table 3 Impact categories, their objects, and units of characterization factors

\begin{tabular}{llc}
\hline \multicolumn{1}{c}{ Impact category } & \multicolumn{1}{c}{ Object } & \multicolumn{1}{c}{$\begin{array}{c}\text { Unit of } \\
\text { characterization factor }\end{array}$} \\
\hline Fossil fuel consumption & Crude oil, Coal, Natural gas & Consumption energy [MJ] \\
Global warming & $\mathrm{CO}_{2}, \mathrm{CH}_{4}, \mathrm{~N}_{2} \mathrm{O}$ & $\mathrm{GWP}$ [kg-CO $\left.\mathrm{CO}_{2} \mathrm{eq}\right]$ \\
Urban area air pollution & $\mathrm{SO}_{\mathrm{x}}, \mathrm{NO}_{\mathrm{x}}, \mathrm{PM}_{2.5}, \mathrm{PM}_{10}$ & $\mathrm{UAF}$ [kg-SO \\
Acidification & $\mathrm{SO}_{2}, \mathrm{NO}_{\mathrm{x}}$ & $\mathrm{DAP}\left[\mathrm{kg}-\mathrm{SO}_{2} \mathrm{eq}\right]$ \\
\hline GWP: global warming potential, UAF: urban air pollution characterization factor, DAP: deposition-oriented acidification potential. \\
For PM2.5 and PM10, characterization factor was not available in LIME2.
\end{tabular}


Table 4 Impact categories and corresponding objects of protection

\begin{tabular}{lcccc}
\hline \multicolumn{1}{c}{ Impact category } & $\begin{array}{l}\text { Human health } \\
\text { [DALY] }\end{array}$ & $\begin{array}{c}\text { Social assets } \\
\text { [Yen] }\end{array}$ & $\begin{array}{c}\text { Biodiversity } \\
\text { [EINES] }\end{array}$ & $\begin{array}{c}\text { Primary } \\
\text { production } \\
\text { [NPP] }\end{array}$ \\
\hline $\begin{array}{l}\text { Fossil fuel consumption } \\
\text { Global warming }\end{array}$ & $\checkmark$ & $\checkmark$ & $\checkmark$ & $\checkmark$ \\
Urban area air pollution & $\checkmark$ & $\checkmark$ & \\
Acidification & & $\checkmark$ & $\checkmark$ \\
\hline $\begin{array}{l}\text { DALY: disability-adjusted life year, Yen: Japanese yen, EINES: expected increase in number of extinct species, NPP: net primary } \\
\text { productivity }\end{array}$
\end{tabular}


Table 5 Scenario setting

\begin{tabular}{|c|c|c|c|c|c|}
\hline & & S1-short & S1-long & S2-short & S3-long \\
\hline \multicolumn{6}{|c|}{ Functional unit 1: Treatment of waste cooking oil ( $\mathrm{kL} / \mathrm{yr}$ ) } \\
\hline Waste cooking oil & Incineration & 1,142 & 1,142 & 947 & 947 \\
\hline \multirow[t]{2}{*}{ from households } & FAME-type BDF or & - & - & 196 & 196 \\
\hline & HBD production & & & & \\
\hline \multirow{3}{*}{$\begin{array}{l}\text { Waste cooking oil } \\
\text { from businesses }\end{array}$} & Incineration & 1,108 & 1,108 & - & - \\
\hline & FAME-type BDF or & - & - & 1,108 & 1,108 \\
\hline & HBD production & & & & \\
\hline \multicolumn{6}{|c|}{ Functional unit 2: Running diesel vehicle for household waste collection ( $k L / y r)$} \\
\hline \multicolumn{2}{|c|}{ Diesel vehicle complied with: } & short & long & short & long \\
\hline \multicolumn{2}{|c|}{ Fossil-derived fuel consumption } & 1,157 & 1,157 & - & 502 \\
\hline \multicolumn{2}{|c|}{ FAME-type BDF consumption } & - & - & 1,252 & - \\
\hline \multicolumn{2}{|l|}{ HBD consumption } & - & - & - & 652 \\
\hline
\end{tabular}

short: the new short-term emission gas standard

long: the new long-term emission gas standard 


\section{Table 6 Important parameters for unit processes}

\begin{tabular}{|c|c|c|c|c|c|}
\hline Process and parameters & & Values & Units & Specific features & References \\
\hline \multicolumn{6}{|l|}{ Collection } \\
\hline \multirow[t]{3}{*}{ Diesel consumption } & $\begin{array}{l}\text { Collected as mixed } \\
\text { waste }\end{array}$ & 0.109 & $\mathrm{~L} / \mathrm{kL}$ of WCO & Allocated basing on weight & Estimated \\
\hline & Source separation & 11.4 & $\mathrm{~L} / \mathrm{kL}$ of WCO & From households & Estimated \\
\hline & Source separation & 9.07 & $\mathrm{~L} / \mathrm{kL}$ of WCO & From businesses & \\
\hline \multicolumn{6}{|l|}{ Incineration with energy recovery } \\
\hline Electricity consumption & & 158 & kWh/ton of WCO & & NIES, 2008; and calculation \\
\hline Electricity production efficiency & & 15.0 & $\%$ & Produced by steam turbine & Assumed \\
\hline \multirow[t]{7}{*}{ Emission factor } & $\mathrm{CH}_{4}$ & 0.120 & $\mathrm{~kg} / \mathrm{ton}$ of carbon & & Yasuda, 1997 \\
\hline & $\mathrm{N}_{2} \mathrm{O}$ & 0.565 & $\mathrm{~kg} / \mathrm{ton}$ of WCO & & MOE, 2009 \\
\hline & $\mathrm{SO}_{\mathrm{x}}$ & 150 & g/ton of WCO & $\begin{array}{l}\text { All sulfur (S) content in waste cooking oil was } \\
\text { assumed to be emitted in this process }\end{array}$ & Calculation \\
\hline & $\mathrm{NO}_{\mathrm{x}}$ & 500 & $\mathrm{~g} / \mathrm{ton}$ of WCO & & Hirai et al., 2001 \\
\hline & $\mathrm{PM}_{2.5}$ & 798 & g/ton of WCO & & Shiota, 2011; and calculation \\
\hline & $\mathrm{PM}_{10}$ & 108 & g/ton of WCO & & Shiota, 2011; and calculation \\
\hline & $\mathrm{CO}_{2}$ & 100 & $\begin{array}{l}\mathrm{kg} / \mathrm{ton} \text { of waste } \\
\text { glycerin }\end{array}$ & & Calculation \\
\hline \multicolumn{6}{|c|}{ FAME-type BDF production by alkali catalysis method } \\
\hline Waste cooking oil consumption & & 1.04 & $\mathrm{~L} / \mathrm{L}$ of $\mathrm{BDF}$ & & Data obtained from Kyoto city \\
\hline Methanol consumption & & 0.131 & $\mathrm{~kg} / \mathrm{L}$ of $\mathrm{BDF}$ & & Data obtained from Kyoto city \\
\hline $\mathrm{KOH}$ consumption & & 7.60 & $\mathrm{~g} / \mathrm{L}$ of BDF & & Data obtained from Kyoto city \\
\hline
\end{tabular}




\begin{tabular}{|c|c|c|c|c|c|}
\hline Paraffin consumption & & 0.0274 & $\mathrm{~L} / \mathrm{L}$ of $\mathrm{BDF}$ & & Data obtained from Kyoto city \\
\hline Electricity consumption & & 0.184 & $\mathrm{~L} / \mathrm{L}$ of $\mathrm{BDF}$ & & Data obtained from Kyoto city \\
\hline Waste glycerin generation & & 0.396 & $\mathrm{~L} / \mathrm{L}$ of BDF & & Data obtained from Kyoto city \\
\hline \multicolumn{6}{|c|}{ HBD production by catalytic cracking and hydrogenation method } \\
\hline Wastewater generation & & 0.0400 & $\mathrm{~L} / \mathrm{L}$ of $\mathrm{WCO}$ & & Data by demonstration test \\
\hline Electricity consumption & & 0.240 & $\mathrm{kWh} / \mathrm{L}$ of WCO & & Data by demonstration test \\
\hline $\mathrm{H}_{2}$ consumption & & 0.0926 & $\mathrm{~m}^{3} / \mathrm{L}$ of WCO & & Data by demonstration test \\
\hline $\mathrm{N}_{2}$ consumption & & 0.125 & $\mathrm{~kg} / \mathrm{L}$ of WCO & Used as carrier gas & Data by demonstration test \\
\hline Heat energy consumption & & 9.07 & $\mathrm{MJ} / \mathrm{L}$ of WCO & Supplied by high- and low-boiling oils, and offgas & Data by demonstration test \\
\hline \multirow[t]{4}{*}{ Products and produced energy } & HBD & 0.50 & $\mathrm{~L} / \mathrm{L}$ of WCO & & Data by demonstration test \\
\hline & High-boiling-point oil & 0.04 & $\mathrm{~L} / \mathrm{L}$ of WCO & & Data by demonstration test \\
\hline & Low-boiling-point oil & 0.16 & $\mathrm{~L} / \mathrm{L}$ of WCO & & Data by demonstration test \\
\hline & Offgas & 0.13 & $\mathrm{~m}^{3} / \mathrm{L}$ of $\mathrm{WCO}$ & & Data by demonstration test \\
\hline Emission factor & $\mathrm{CH}_{4}$ & 0.00590 & $\mathrm{~kg} / \mathrm{m}^{3}$ of wastewater & & MOE et al., 2012 \\
\hline \multicolumn{6}{|l|}{ Diesel fuel production } \\
\hline Electricity consumption & & 0.0075 & $\mathrm{kWh} / \mathrm{L}$ & & JLCA, 2013 \\
\hline \multirow[t]{4}{*}{ Emission factor } & $\mathrm{CO}_{2}$ & 0.091 & $g / L$ & & JLCA, 2013 \\
\hline & $\mathrm{SO}_{\mathrm{x}}$ & 0.087 & $\mathrm{~g} / \mathrm{L}$ & & JLCA, 2013 \\
\hline & $\mathrm{NO}_{\mathrm{x}}$ & 0.071 & $\mathrm{~g} / \mathrm{L}$ & & JLCA, 2013 \\
\hline & PM & $9.0 \times 10^{-5}$ & $\mathrm{~g} / \mathrm{L}$ & All $\mathrm{PM}$ was regarded as $\mathrm{PM}_{10}$ & JLCA, 2013 \\
\hline \multicolumn{6}{|l|}{ Running household waste collection vehicle } \\
\hline Emission factor & $\mathrm{CO}_{2}$ & 2.62 & $\mathrm{~kg} / \mathrm{L}$ & & MOE, 2009 \\
\hline \multirow[t]{2}{*}{ (diesel fuel, new short-term st.) } & $\mathrm{SO}_{\mathrm{X}}$ & 1.16 & $g / L$ & $\begin{array}{l}\text { All sulfur (S) content in diesel fuel was assumed to be } \\
\text { emitted in this process }\end{array}$ & Calculation \\
\hline & $\mathrm{NO}_{\mathrm{X}}$ & 18.8 & $g / L$ & & Emission testing, calculation \\
\hline
\end{tabular}




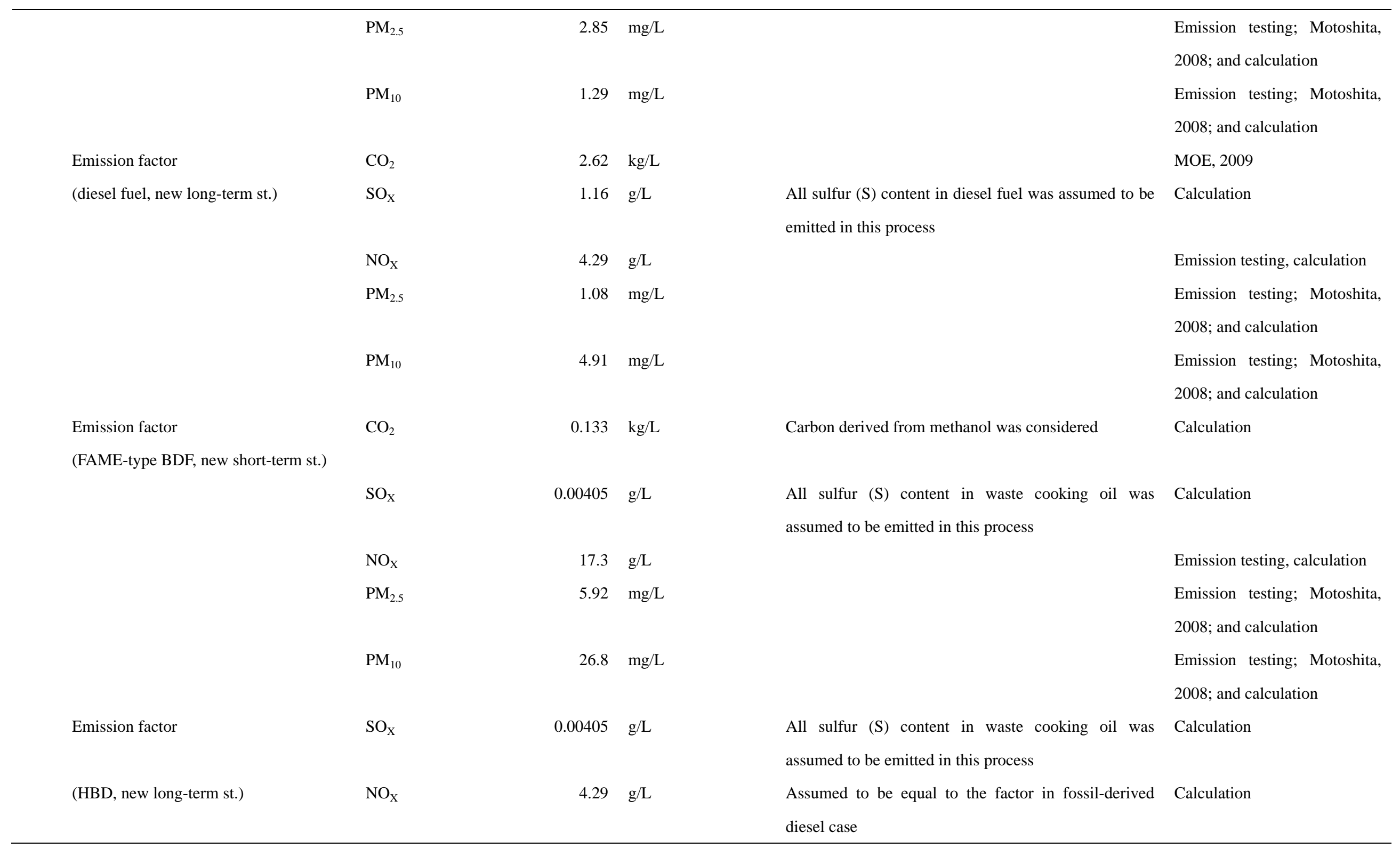




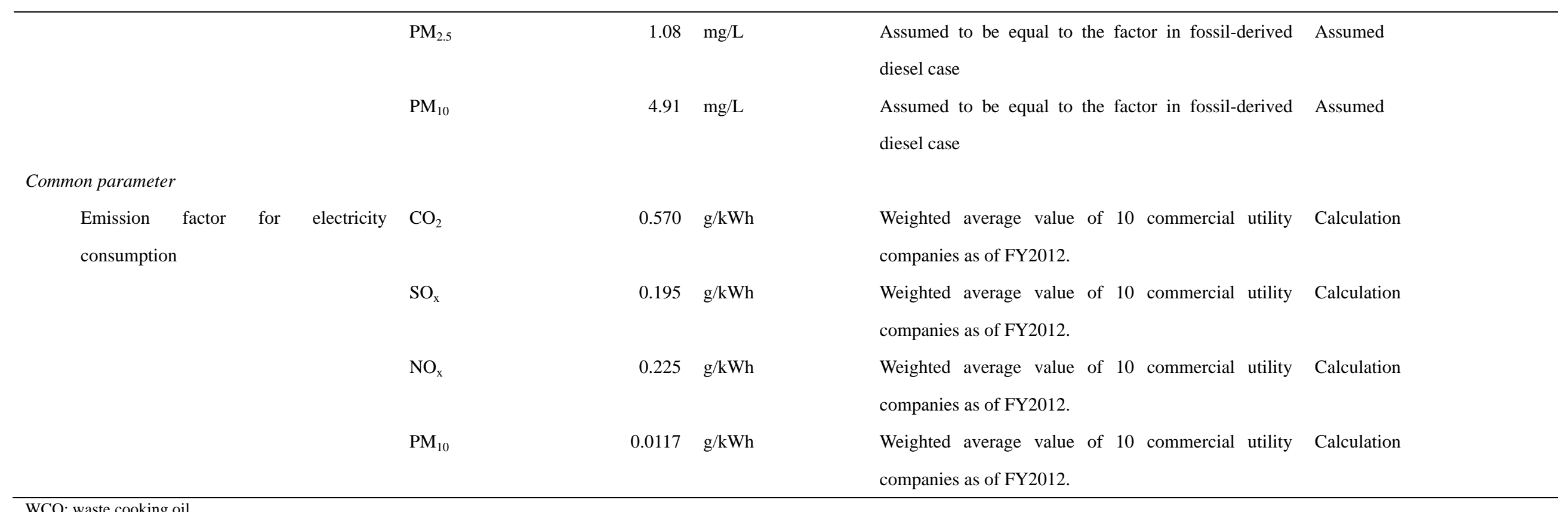


Table 7 Summary of damage assessment

\begin{tabular}{llrrrr}
\hline & & S1-short & S1-long & S2-short & S3-long \\
\hline Human health & [DALY] & 1.10 & 0.60 & 0.69 & 0.32 \\
Social assets & {$[$ Million Yen] } & 5.08 & 3.64 & 2.02 & 1.43 \\
Biodiversity & {$\left[\times 10^{-10}\right.$ EINES] } & -27.4 & -27.4 & -9.87 & -8.40 \\
Primary Production & {$\left[\times 10^{3} \mathrm{NPP}\right]$} & 2.49 & -1.51 & 4.21 & 0.48 \\
\hline
\end{tabular}


Table 8 Parameters considered in uncertainty analysis

\begin{tabular}{|c|c|c|c|c|}
\hline & & Min. & Default & Max. \\
\hline \multicolumn{5}{|c|}{ A) EFs: electricity consumption (g/kWh) } \\
\hline & $\mathrm{CO}_{2}$ & 0.412 & 0.570 & 0.570 \\
\hline & $\mathrm{SO}_{\mathrm{x}}$ & 0.138 & 0.195 & 0.195 \\
\hline & $\mathrm{NO}_{\mathrm{x}}$ & 0.170 & 0.225 & 0.225 \\
\hline \multicolumn{5}{|c|}{ B) Electricity production efficiency at incineration facility } \\
\hline & & $0 \%$ & $15 \%$ & $20 \%$ \\
\hline \multicolumn{5}{|c|}{ C) $\mathrm{EF}$ of $\mathrm{NO}_{\mathrm{x}}$ : exhaust gas from household waste collection vehicle $(\mathrm{g} / \mathrm{L})$} \\
\hline & Diesel, the new short-term st. & 16.2 & 18.8 & - \\
\hline & Diesel, the new long-term st. & 3.32 & 4.29 & 10.1 \\
\hline & FAME-type BDF, the new short-term st. & 16.2 & 17.3 & - \\
\hline & HBD, the new long-term st. & 3.32 & 4.29 & 10.1 \\
\hline \multicolumn{5}{|c|}{ D) EF of $\mathrm{PM}_{2.5}$ : incineration facility (mg/ton of WCO) } \\
\hline & & 37.2 & 798 & 1999 \\
\hline
\end{tabular}


$<$ S1-short, S1-long scenarios $>$

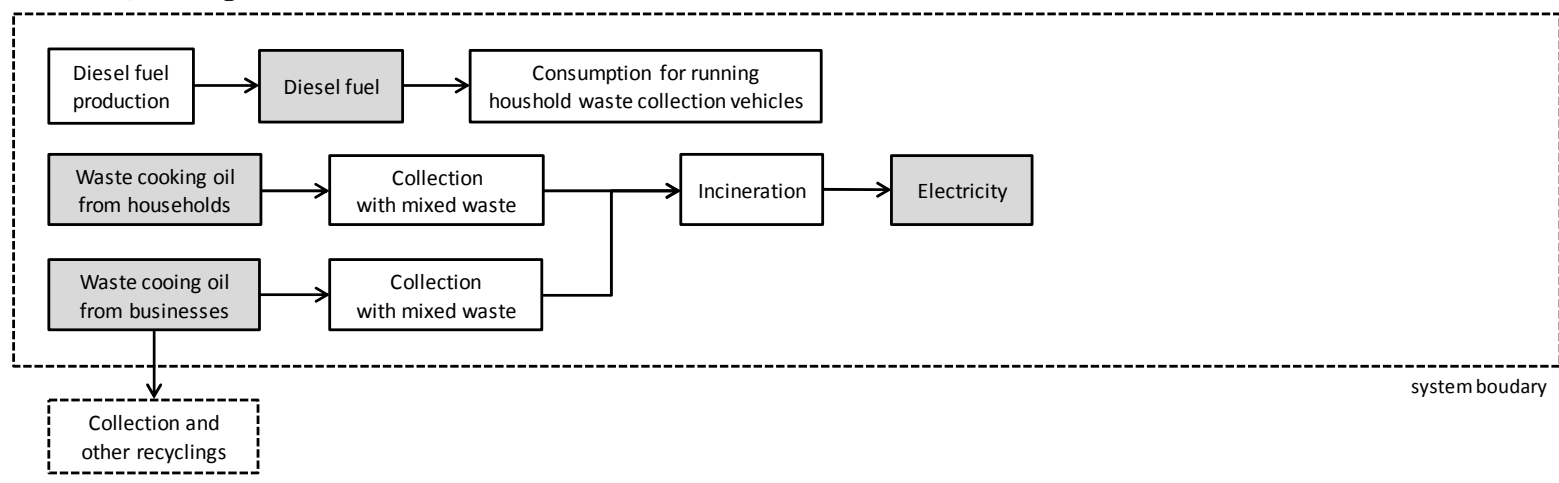

$<$ S2-short scenario $>$

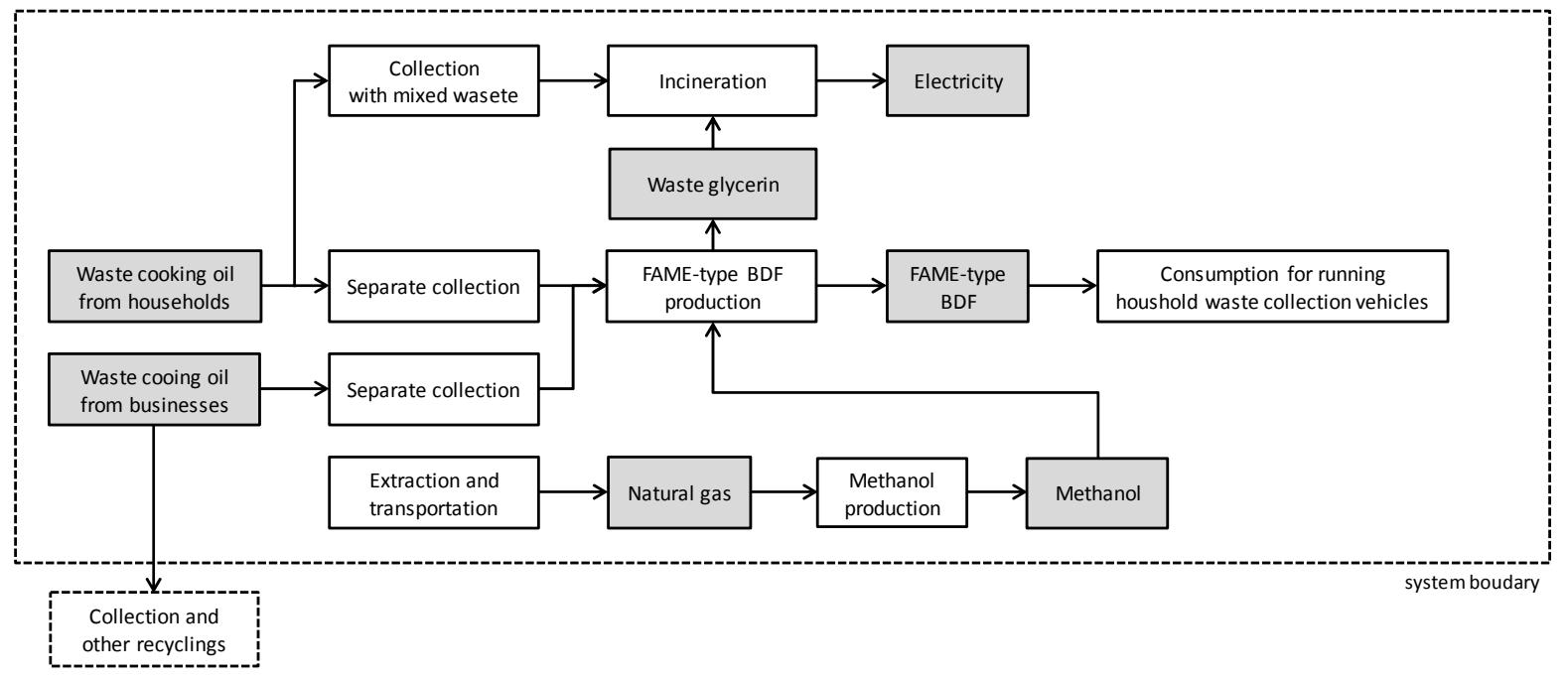

$<$ S3-long scenario $>$

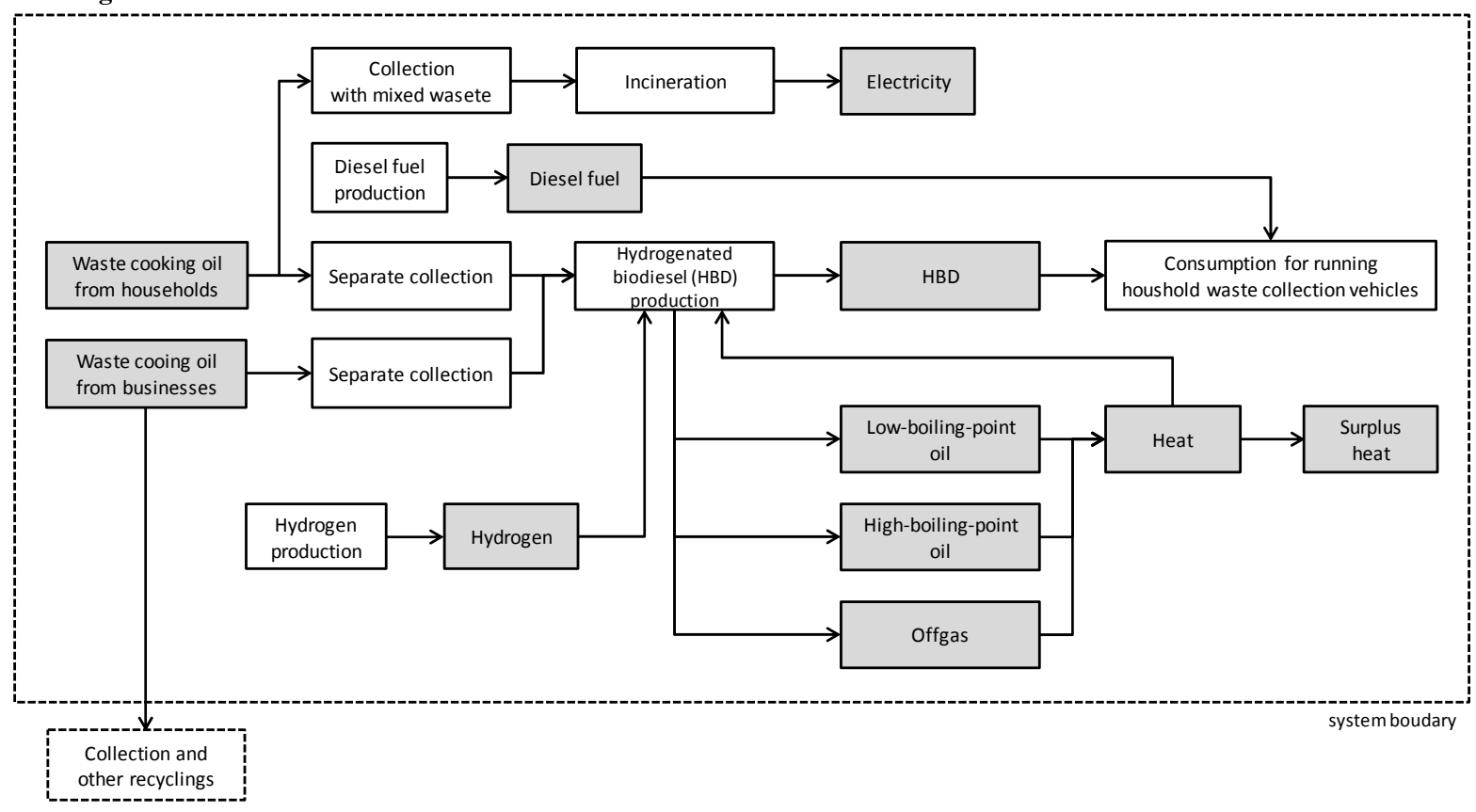

Fig. 1 System flow of each scenario

White boxes: processes, black boxes: products and energy, dotted white boxes: excluded processes. 


\section{Wollection}

Diesel fuel production

BDF (HBD) production

Runnning household waste collection vehicle (BDF)

ـurplus low-boiling point oil supply

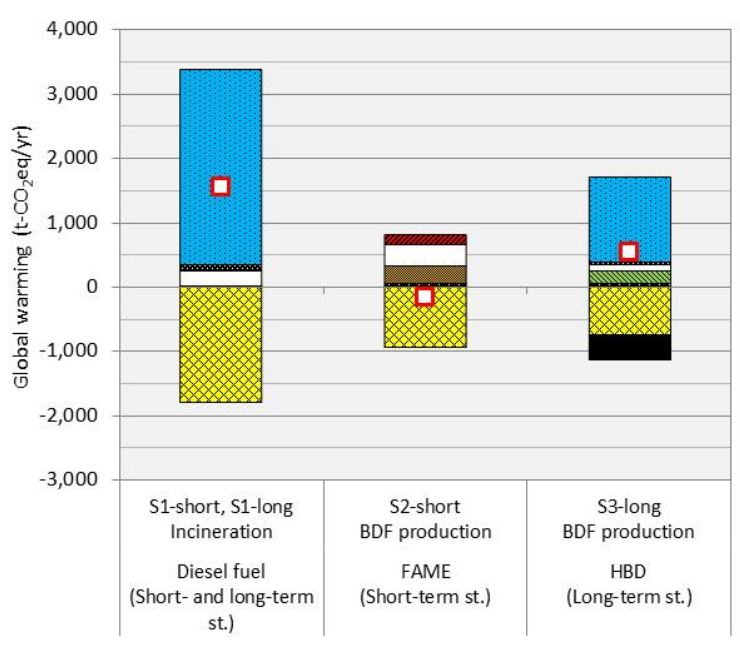

(a) Global warming

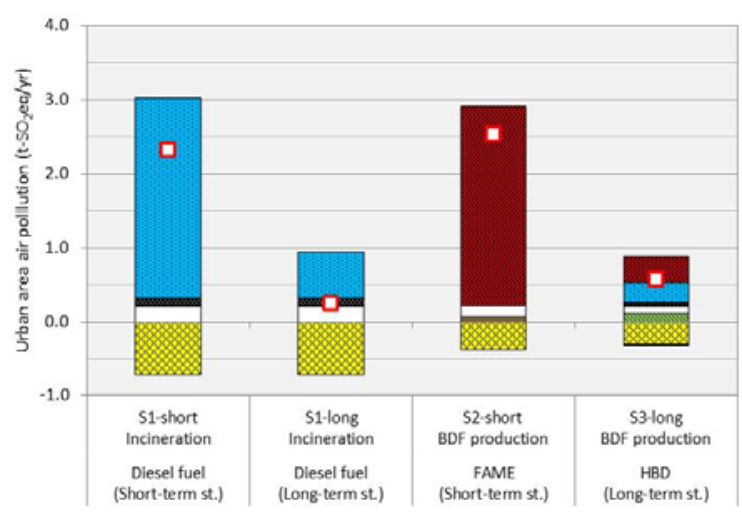

(c) Urban area air pollution

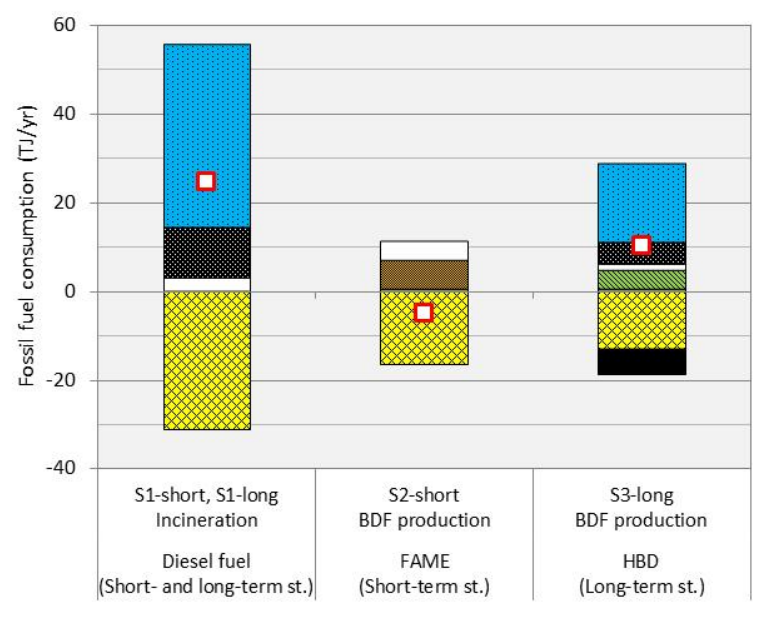

(b) Fossil fuel consumption

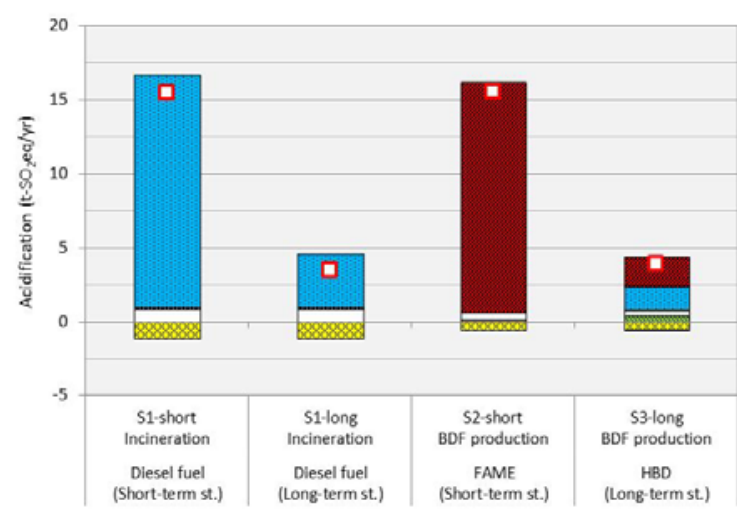

(d) Acidification

Fig. 2 Results of characterization 

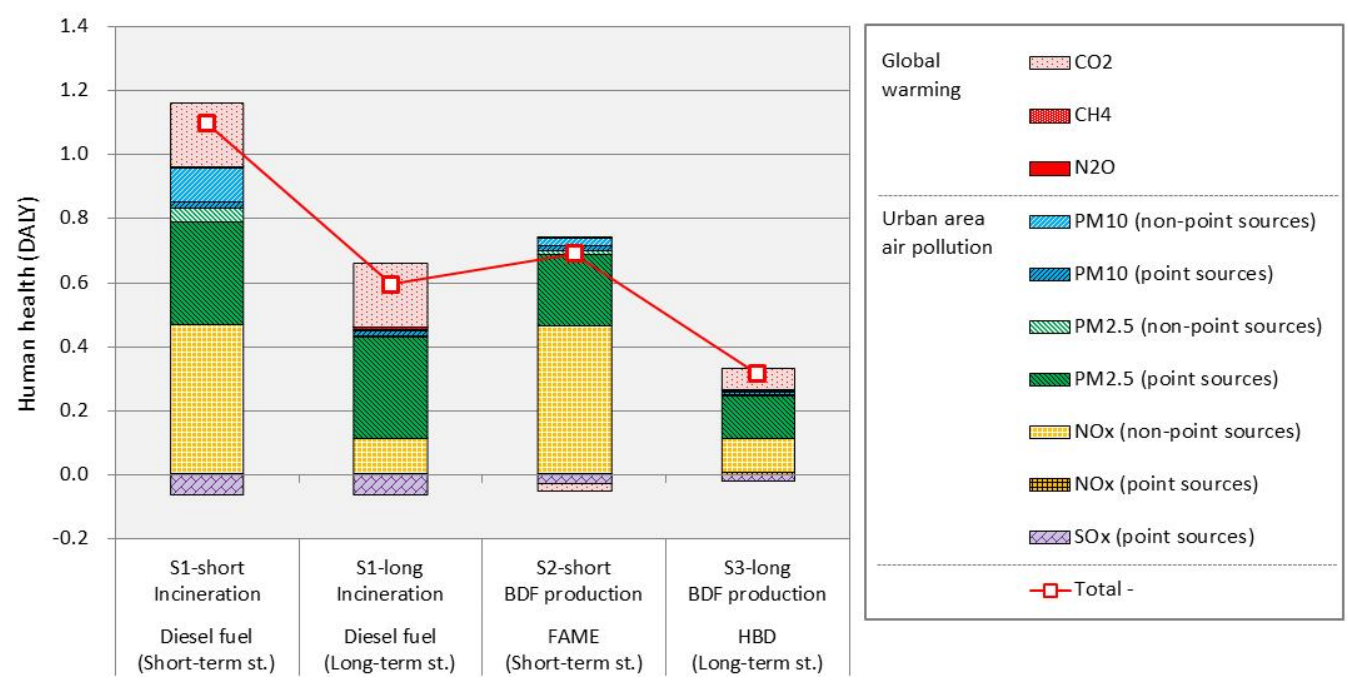

(a) Human health
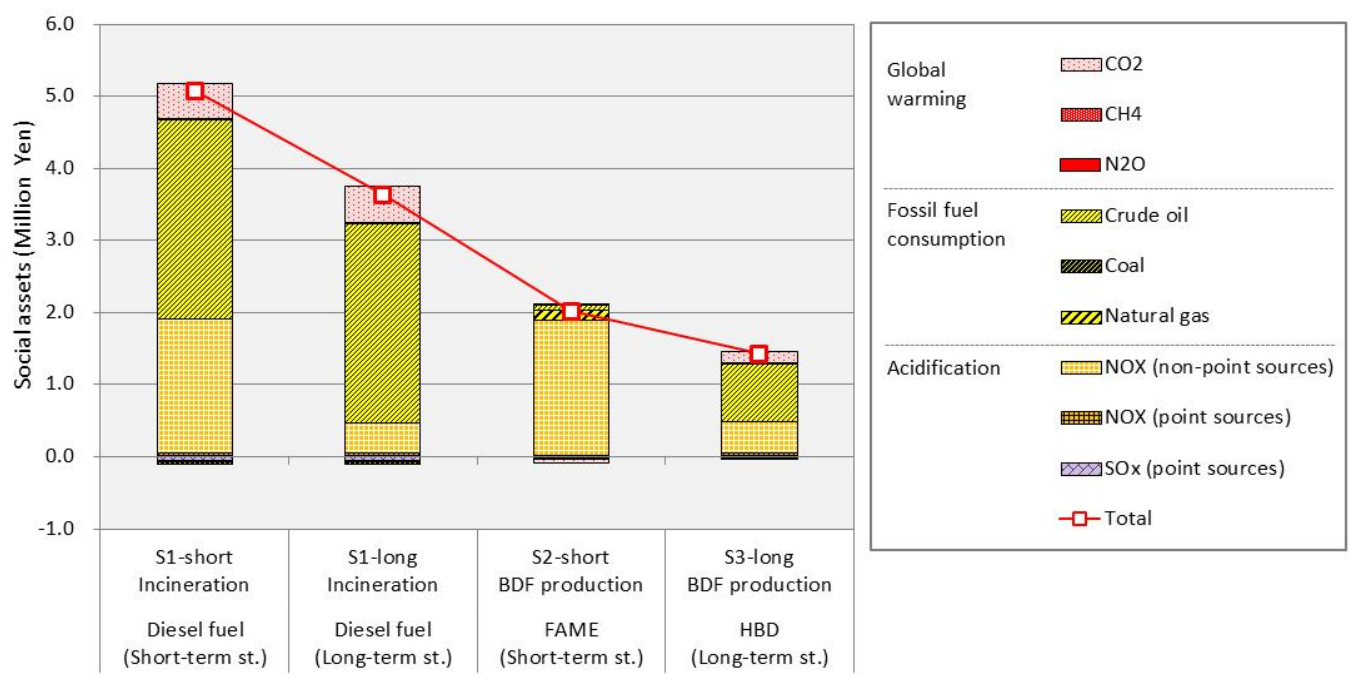

(b) Social assets

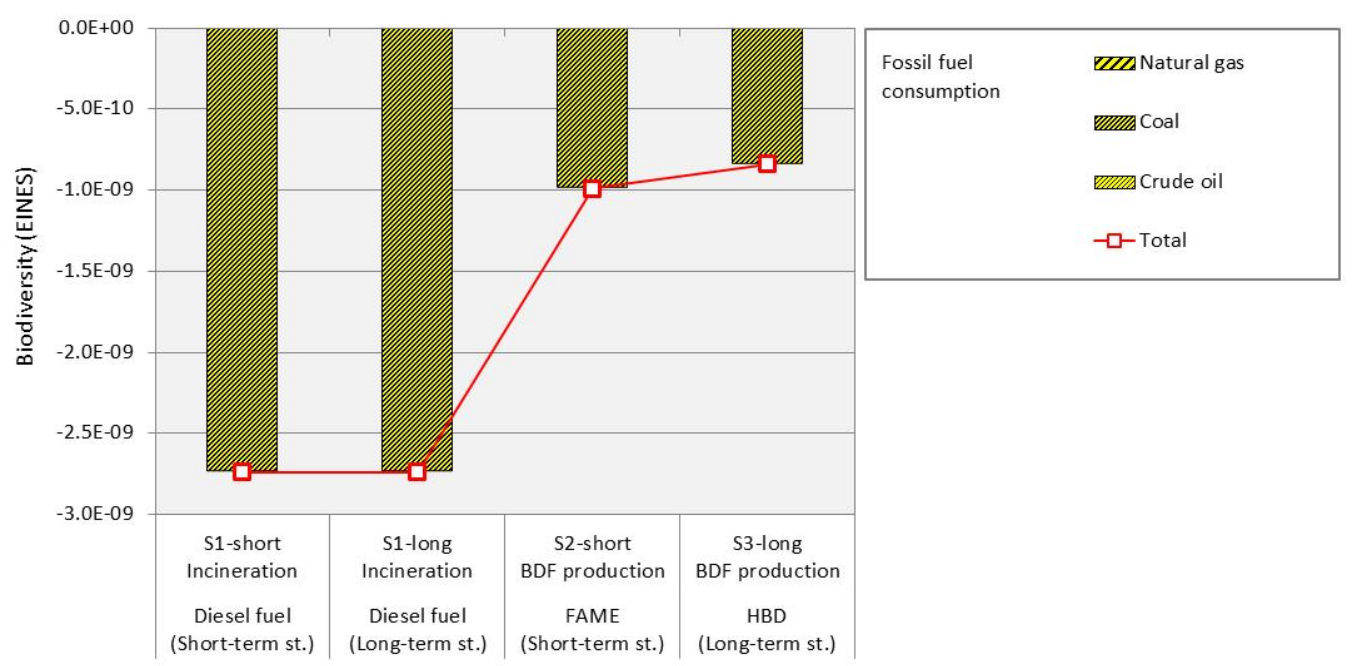

(c) Biodiversity 

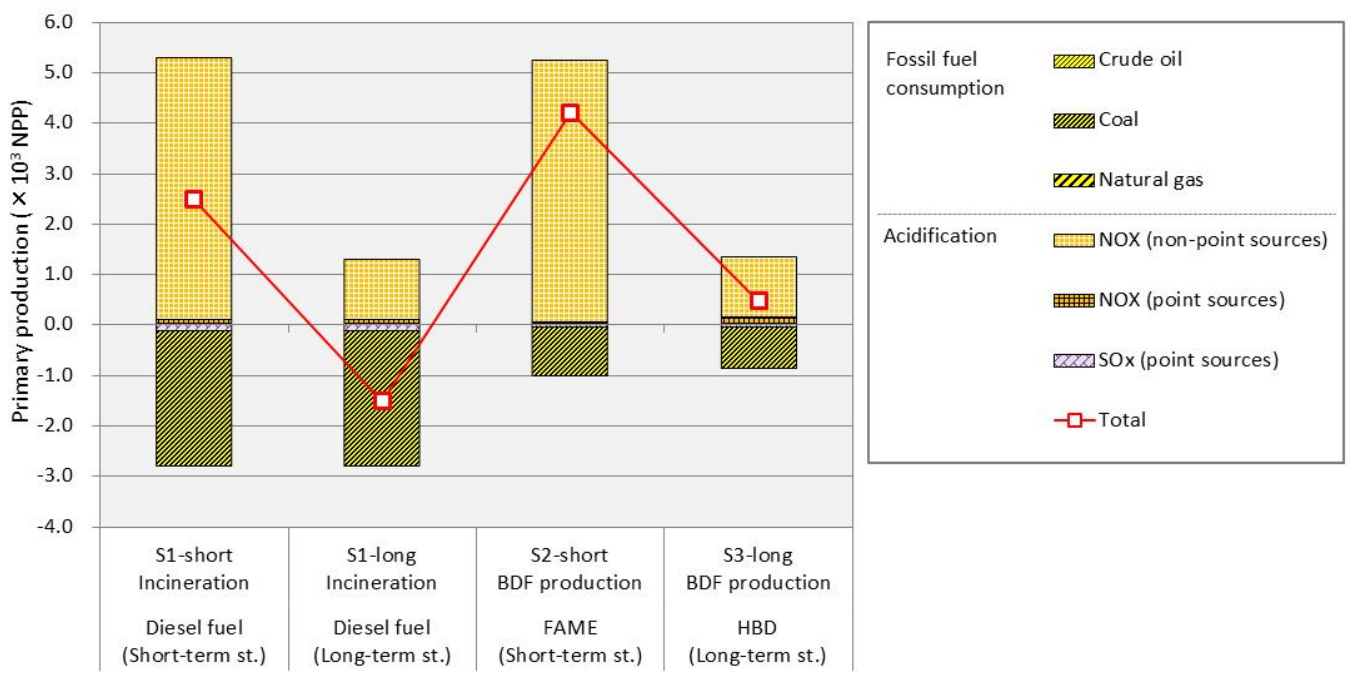

(d) Primary Production

\section{Fig. 3 Results of damage assessment}

Point sources: emissions from facilities, non-point sources: emissions from diesel vehicles. 


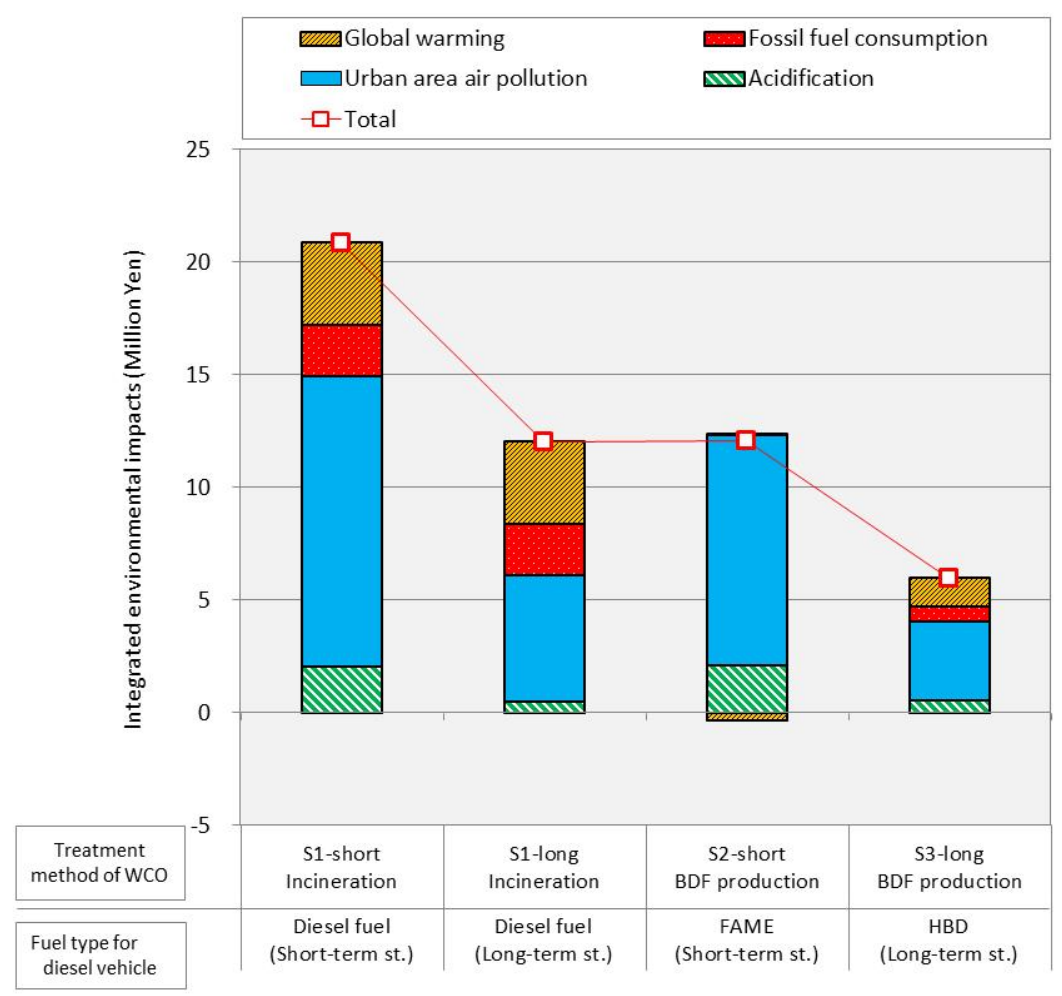

Fig. 4 Integrated environmental impact of each scenario

WCO: waste cooking oil, Short-term st.: new short-term emissions gas standard, Long-term st.: new long-term emissions gas standard. 

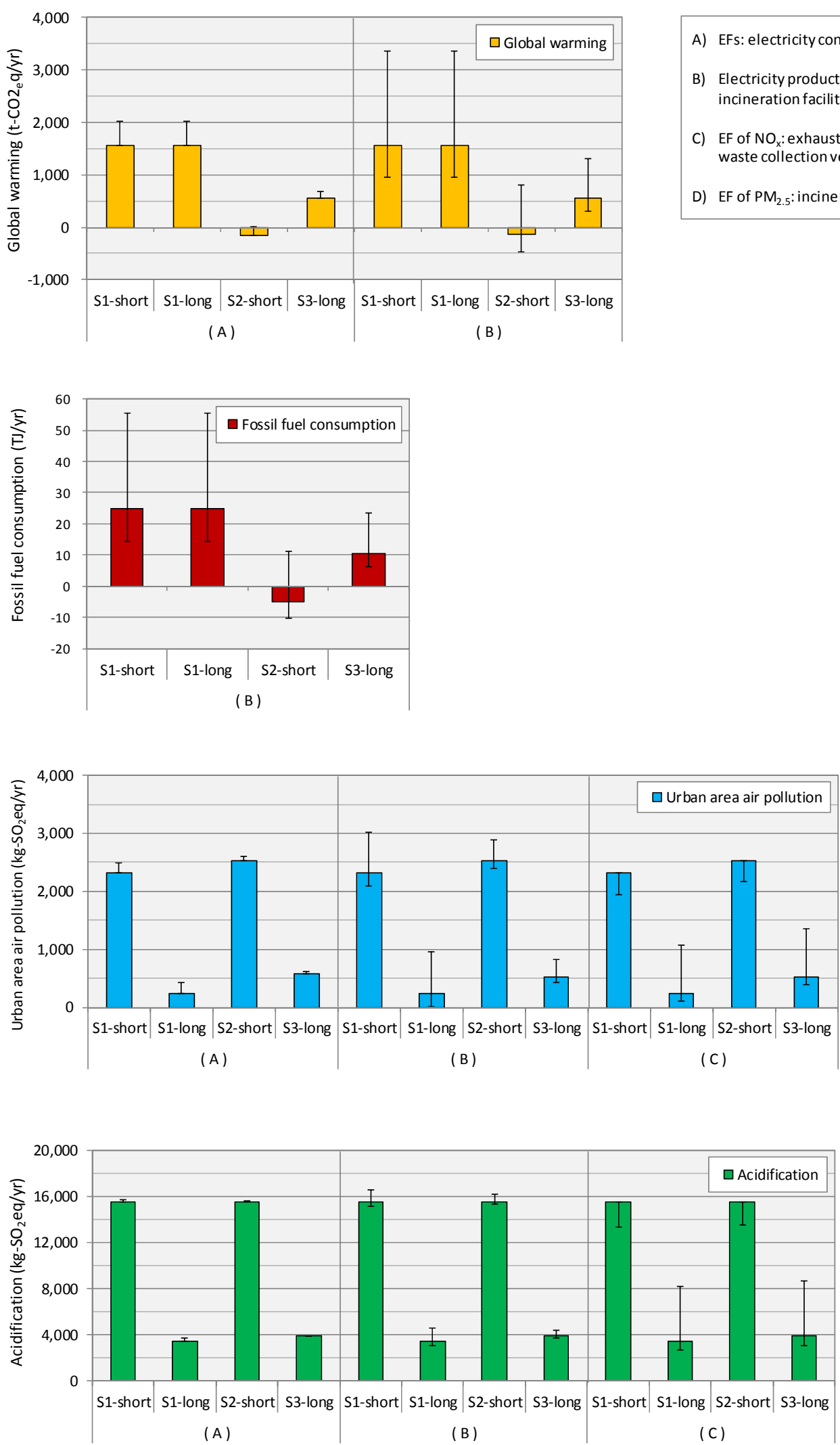

Fig. 5 Results of uncertainty analysis (Characterization)

Uncertainties are shown as a range (Min.-Max.).
( A )

(B)

( C)
(A)

(B)

(C)
A) EFs: electricity consumption

B) Electricity production efficiency at incineration facility

C) $\mathrm{EF}$ of $\mathrm{NO}_{\mathrm{x}}$ : exhaust gas from household waste collection vehicle

D) $\mathrm{EF}$ of $\mathrm{PM}_{2.5}$ : incineration facility 

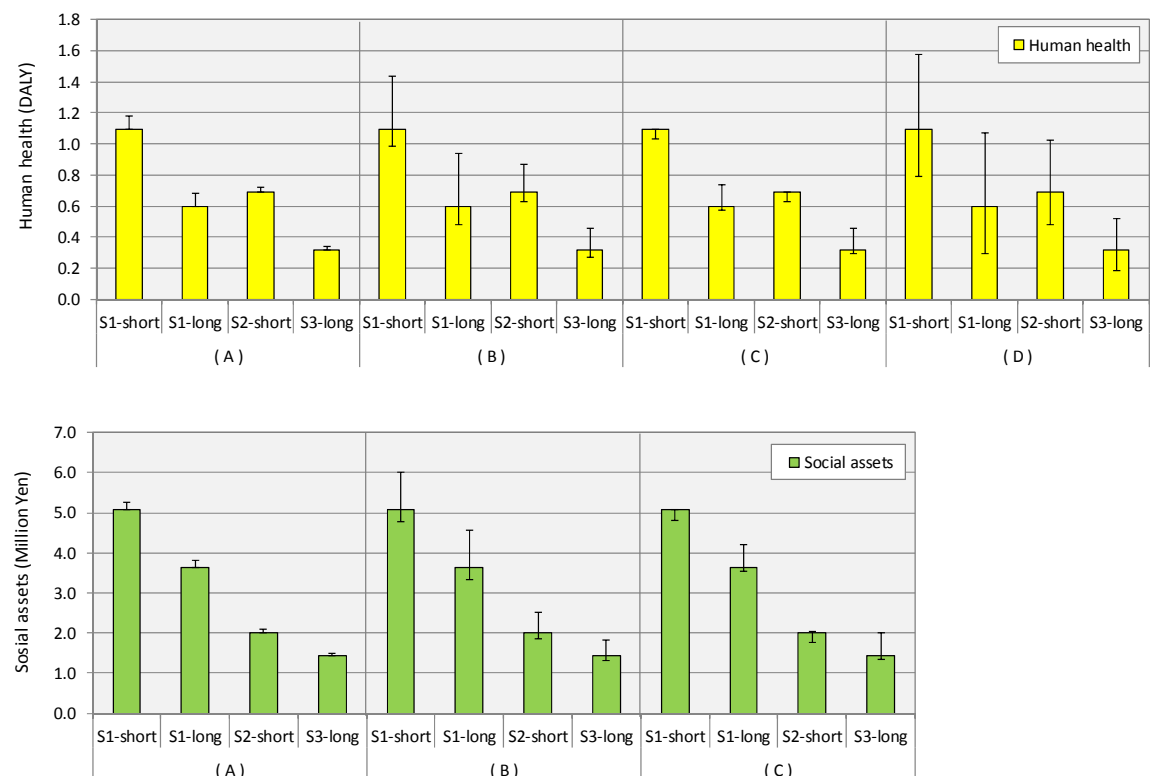

(A)
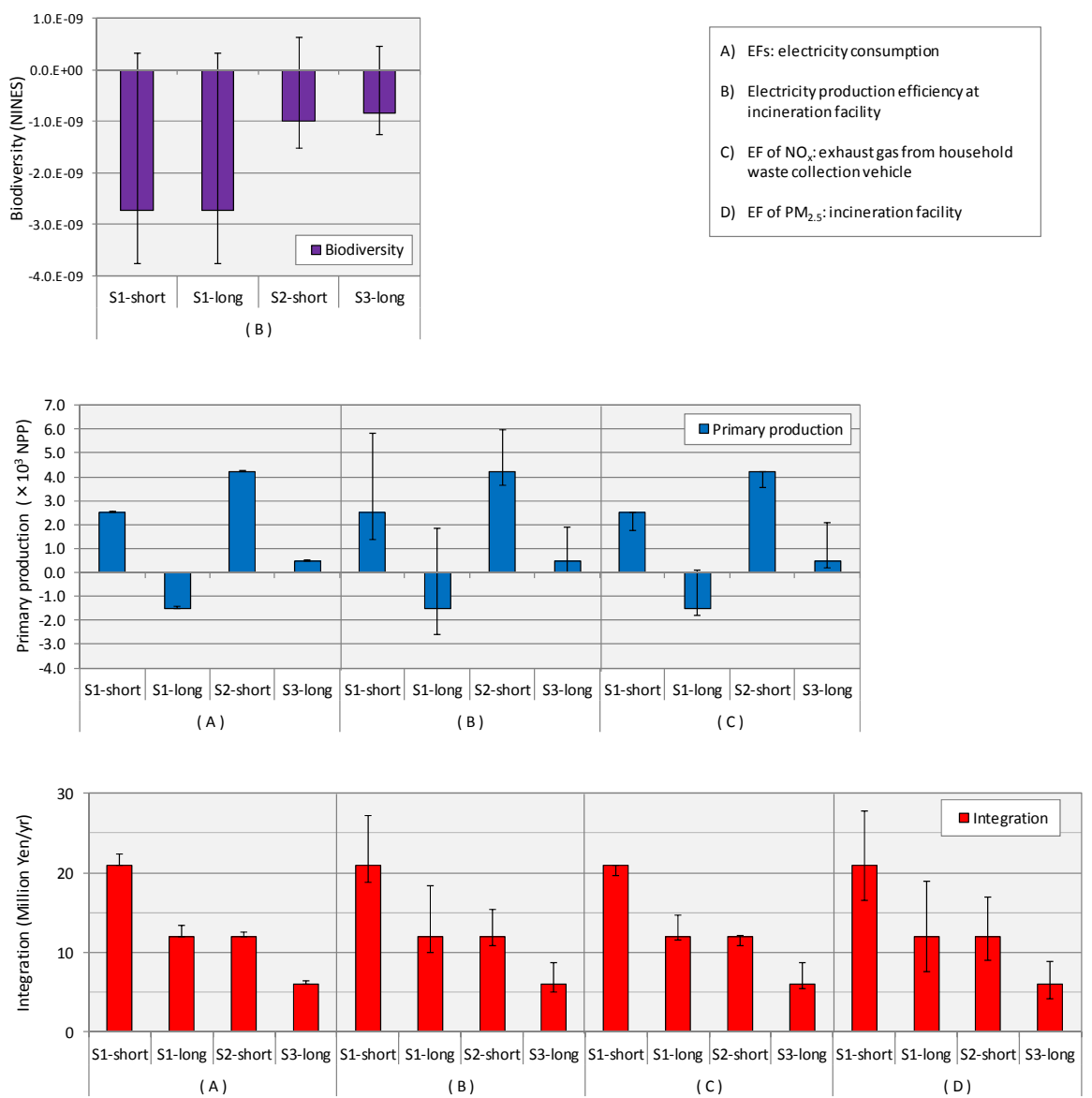

Fig. 6 Results of uncertainty analysis (Damage assessment and integration)

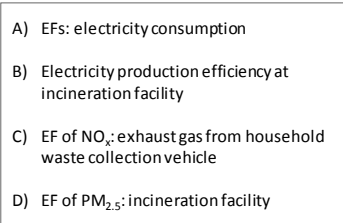

D) $\mathrm{EF}$ of $\mathrm{PM}_{2.5}$ : incineration facility

Uncertainties are shown as a range (Min.-Max.). 
$<$ Electronic supplementary material>

Life Cycle Assessment of Hydrogenated Biodiesel Production from Waste Cooking Oil Using the Catalytic Cracking and Hydrogenation Method

Waste Management, http://www.journals.elsevier.com/waste-management/

Junya YANO, Tatsuki AOKI, Kazuo NAKAMURA, Kazuo YAMADA, Shin-ichi SAKAI

Environment Preservation Research Center, Kyoto University,

Yoshida-Honmachi, Sakyo-ku, Kyoto 606-8501, Japan

E-mail: yano@eprc.kyoto-u.ac.jp

Table 1 Characteristics of fossil-derived diesel fuel and BDFs

\begin{tabular}{|c|c|c|c|c|}
\hline & $\begin{array}{l}\text { Fossil-derived } \\
\text { diesel fuel }\end{array}$ & $\begin{array}{l}\text { Produced at } \\
\text { Kyoto city }\end{array}$ & $\begin{array}{l}\text { HBD } \\
\text { Produced in } \\
\text { the demonstration } \\
\text { project at } \\
\text { Kyoto city* } \\
\text { (ASTEM, 2013) }\end{array}$ & $\begin{array}{c}\text { NExBTL } \\
\text { (Neste Oil, 2014) }\end{array}$ \\
\hline Density at $15^{\circ} \mathrm{C}(\mathrm{kg} / \mathrm{L})$ & 0.823 & 0.884 & 0.844 & $0.77-0.79$ \\
\hline $\begin{array}{l}\text { Kinetic viscosity at } \\
40^{\circ} \mathrm{C}(-)\end{array}$ & 4.3 & 4.59 & 3.2 & $2.0-4.0$ \\
\hline Flash point $\left({ }^{\circ} \mathrm{C}\right)$ & - & 135 & 50 & $>61$ \\
\hline Cetane index & 56.3 & 52.5 & 51.7 & $>70.0$ \\
\hline $\begin{array}{l}90 \% \text { distillation point } \\
\left({ }^{\circ} \mathrm{C}\right)\end{array}$ & 329 & - & 360 & $\begin{array}{r}<320 \\
(95 \% \text { distillation })\end{array}$ \\
\hline $\begin{array}{l}\text { Oxidation stability } \\
\text { (Rancimat method) }\end{array}$ & $>48$ & 5.9 & $>36$ & $<25$ \\
\hline Pour point $\left({ }^{\circ} \mathrm{C}\right)$ & - & -2.5 & -13.1 & - \\
\hline Clogging point $\left({ }^{\circ} \mathrm{C}\right)$ & - & -5 & -4 & - \\
\hline $\begin{array}{l}\text { Lower heating value } \\
(\mathrm{MJ} / \mathrm{kg})\end{array}$ & 44.1 & 37.2 & 42.6 & 44.1 \\
\hline C (wt\%) & 86.0 & 77.1 & 85.9 & - \\
\hline $\mathrm{H}(\mathrm{wt} \%)$ & 12.5 & 11.9 & 12.6 & - \\
\hline $\mathrm{O}(\mathrm{wt} \%)$ & $<0.5$ & 10.8 & $<0.5$ & - \\
\hline
\end{tabular}


Table 2 Characteristics of waste glycerin

\begin{tabular}{lrl}
\hline Moisture content & 22.0 & $\mathrm{wt} \%$ \\
Glycerin & 47.3 & $\mathrm{wt} \%$ \\
Methanol & 5.2 & $\mathrm{wt} \%$ \\
Potassium (K) & 3.2 & $\mathrm{wt} \%$ \\
Oily fraction & 22.4 & $\mathrm{wt} \%$ \\
Elemental composition & & \\
$\quad$ Biomass-based carbon (C) & 93.0 & $\mathrm{wt} \%$ \\
Fossil-derived carbon (C) & 7.0 & $\mathrm{wt} \%$ \\
\hline
\end{tabular}

\section{References}

ASTEM, 2013. Report on R\&D towards the utilization of 2nd generation biodiesel suitable for vehicles. Kyoto, Japan (in Japanese).

Neste Oil, 2014. Hydrotreated vegetable oil (HVO) - premium renewable biofuel for diesel engines. 